Украӥнський нумізматичний щорічник. Вип. 1.

УДК 93/94(474.5/477):737.1/327～DOI https://doi.org/10.31470/2616-6275-2017-1-37-74

Василь Орлик

доктор історичних наук, професор завідувач кафедри суспільних наук, інформаційної та архівної справи Центральноукраїнський національний технічний університет (Кропивницький) Україна v.m.orlik@gmail.com

Dr. hab. Prof. Vasyl Orlyk Head of the Department of Social Sciences, Informational and Archival Affairs Central Ukrainian National Technical University Kropyvnytskyi, Ukraine v.m.orlik@gmail.com

\title{
ТОПОГРАФІЯ ЗНАХІДОК В УКРАЇНІ МОНЕТ ДЕРЖАВИ ТЕВТОНСЬКОГО ОРДЕНУ В ПРУССІЇ ТА ЇЇ ЛІВОНСЬКОГО ВІДДІЛЕННЯ (ЗВЕДЕНІ ВІДОМОСТІ ПО ОБЛАСТЯХ)
}

\section{THE TOPOGRAPHY OF FINDINGS OF COINS OF THE STATE OF THE TEUTONIC ORDER IN PRUSSIA AND ITS LIVONIAN BRANCH IN UKRAINE (SUMMARISED INFORMATION BY REGIONS).}

\begin{abstract}
Анотація
Процес становлення та розвитку зв'язків українських середньовічних земель 3 державою Тевтонського ордену в Пруссії відображений переважно у писемних джерелах, зокрема документальних, другої половини XIII ст. - початку XVI ст. Проте такі зв'язки мали залишити слід не лише в писемних джерелах. Подібні зв'язки, навіть якщо вони часом були і епізодичними, залишають в культурних шарах поселень достатню кількість нумізматичних джерел, у даному випадку тевтонських монет, загублених у свій час їхніми власниками. Метою статті є вивчення та введення до наукового обігу корпусу нумізматичних джерел, які відображають зв'язки українських середньовічних земель 3 державою Тевтонського ордену в Пруссії. Основними нумізматичними джерелами $є$ монетні знахідки, поряд із власне монетами та матеріалами й інструментами монетного карбування. Саме монетні знахідки дозволяють не лише поглибити існуючі на сьогодні уявлення про грошовий обіг i торговельні взаємовідносини, але й часом змінити усталені стереотипи. Звернемося до проблеми участі монет держави хрестоносців - держави Тевтонського ордену в Пруссії, у грошовому обігу на теренах середньовічної України.

Монети Тевтонського ордену зустрічаються в Україні як поодинокі знахідки, так і у складі грошових та грошово-речових скарбів. Дана проблема знайшла певне відображення в науковій літературі. Перші відомості про такі знахідки з'являються у другій половині XIX на початку XX ст., зокрема у працях К. Страшкевича, у матеріалах Археологічних з'їздів. В українській радянській історіографії ігнорувалася участь тевтонських монет в грошовому обігу українських середньовічних земель, а також знахідки цих монет в Україні. В останні десятиліття відбуваються процеси переосмислення історичного минулого. Не стало винятком і вивчення проблем історії держави Тевтонського ордену в Пруссії, в тому числі й взаємин цієї держави хрестоносців з правителями і населенням середньовічної України. У сучасній українській історіографії деякі аспекти проблеми знахідок монет держави Тевтонського ордену в Пруссії на території України відображені у працях Г. Івакіна, А. Позіховського та Р. Шуста, С. Демидко, О. Погорільця і С. Стопенчука, А. Шестопала, Р. Саввова, В. Орлика та ін. Окрім згаданих праць дослідників, відомості про знахідки в Україні монет держави Тевтонського ордену в Пруссії містяться у різнопланових джерелах: архівних документах, музейних колекціях, свідченнях краєзнавців та матеріалах форумів скарбошукачів.
\end{abstract}


The Ukrainian Numismatic Annual, Issue 1.

Дослідження знахідок монет держави Тевтонського ордену в Пруссії на території сучасної України дозволяє зробити висновок про зв'язки (переважно економічні) іiї середньовічних земель 3 Тевтонським орденом і про присутність орденських монет у грошовому обігу на українських теренах у XIV - XV ст. Порушена нами проблема потребує подальшої наукової розробки. Перш за все, грунтовного вивчення нумізматичних колекцій Національного музею історії України, обласних та районних краєзнавчих музеїв, звітів Інституту археології НАН України, опублікованих документів XIV - XV ст., фондів Центрального державного історичного архіву України в містах Києві та Львові, а також міських архівів Торуня, Гданська, Калінінграда (Кенігсберга) та ін. Таким чином, для подальшого комплексного дослідження зв'язків українських середньовічних земель із державою Тевтонського ордену в Пруссії необхідно використовувати різнопланові джерела, в тому числі й нумізматичні, серед яких топографія знахідок монет, безперечно, посідає вагоме місце.

\section{Abstract}

The process of formation and development of the inter-state relations of the Ukrainian medieval lands with the state of the Teutonic Order in Prussia is represented mainly in written sources of the second half of the XIII - beginning of the XVI century, and particularly in documents. However, these relations should have left a mark not only in written sources. The relations, even if they were occasional, leave a sufficient number of numismatic sources in the cultural layers of settlements. In this case they are the Teutonic coins which were lost by their owners in their time. The purpose of the article is to study and introduce into scientific circulation the corpus of numismatic sources which reflect the relations of the Ukrainian medieval lands with the State of the Teutonic Order in Prussia. The main numismatic sources are the coin findings with the coins and materials and tools for coin mining. Coin findings allow enhancing the existing concepts of money circulation and trade relations as well as sometimes these findings change the established stereotypes. Let us turn to the problem of coins of the State of the Crusaders - the State of the Teutonic Order in Prussia, and the monetary circulation in the medieval Ukraine.

The coins of the Teutonic Order are found in Ukraine as one of a kind as well as in money and material hoards. This problem has been studied in the scientific literature. The first information about such findings appeared in the second half of the nineteenth and early twentieth centuries, particularly in the works of K. Strashkevych, in the materials of the Archaeological Congresses. The Ukrainian Soviet historiography ignored the presence of the Teutonic coins in the monetary circulation of Ukrainian medieval lands, as well as the findings of these coins in Ukraine. Recent decades have brought the processes of rethinking of the historical past. The study of the problems of the history of the state of the Teutonic Order in Prussia, including the relations of this state with the rulers and the population of medieval Ukraine, was also no exception. In modern Ukrainian historiography, some aspects of the problem of finding the coins of the State of the Teutonic Order in Prussia on the territory of Ukraine are reflected in the works of H. Ivakin, A. Pozikhovskyi and R. Shust, S. Demydko, O. Pohorilets and S. Stopenchuk, A. Shestopal, R. Savvov, V. Orlyk and others. In addition to the works mentioned above, the information about coin findings of the State of the Teutonic Order in Prussia in Ukraine can be found in various sources: archival documents, museum collections, confirmations of ethnographers and materials of forum for treasure hunters.

The investigation of coin findings of the State of the Teutonic Order in Prussia on the territory of modern Ukraine makes it possible to conclude about the relations (mostly economic) of its medieval lands with the Teutonic Order and the presence of the Order coins in circulation in Ukrainian territories in the XIV-XV centuries. The problem we encountered requires further scientific development. First of all, a detailed study of the numismatic collections of the National Museum of History of Ukraine, regional and district local history museums, reports of the Institute of Archaeology of the National Academy of Sciences of Ukraine, published documents of the XIVXV centuries, funds of the Central State Historical Archives of Ukraine in the cities of Kyiv and Lviv, as well as Torun city archives, Gdansk, Kaliningrad (Königsberg) and others. Thus, for further comprehensive study of the relations of the Ukrainian medieval lands with the state of the Teutonic Order in Prussia, it is necessary to use various sources including numismatic ones. And the topography of the findings of coins undoubtedly holds a significant place. 
Ключові слова: Тевтонський орден, монети, нумізматичні джерела, українські середньовічні землі, Велике князівство Литовське.

Key words: Teutonic Order, coins, numismatic sources, the Ukrainian medieval lands, the Grand Duchy of Lithuania.

Процес становлення та розвитку зв'язків українських середньовічних земель 3 державою Тевтонського ордену в Пруссії відображений переважно у писемних джерелах, зокрема документальних, другої половини XIII ст. - початку XVI ст. Проте такі зв'язки мали залишити слід не лише в писемних джерелах. Подібні зв'язки, навіть якщо вони часом і були епізодичними, залишають в культурних шарах поселень достатню кількість нумізматичних джерел, у даному випадку тевтонських монет, загублених у свій час їхніми власниками. Знахідки монет, за висловом Миколи Котляра, є «реліктами внутрішньої і зовнішньої торгівлі тих часів» ${ }^{1}$.

Метою нашої статті $є$ введення до наукового обігу одного 3 основних нумізматичних джерел - топографії монетних знахідок, які відображають зв’язки українських середньовічних земель $з$ державою Тевтонського ордену в Пруссії. Саме монетні знахідки дозволяють не лише поглибити існуючі на сьогодні уявлення про грошовий обіг і торговельні взаємовідносини, але й часом змінити усталені стереотипи. Монети Тевтонського ордену зустрічаються в Україні як поодинокі знахідки, так і у складі грошових та грошово-речових скарбів. Дана проблема знайшла певне відображення в науковій літературі. Перші відомості про такі знахідки з'являються у другій половині XIX - на початку XX ст., зокрема в працях К. Страшкевича ${ }^{2}$, у матеріалах Археологічних з'їздів ${ }^{3}$. В українській радянській історіографії ігнорувалася участь тевтонських монет в грошовому обігу українських середньовічних земель, а також знахідки цих монет в Україні. В останні десятиліття відбуваються процеси переосмислення історичного минулого. Не стало винятком і вивчення проблем історії держави Тевтонського ордену в Пруссії, в тому числі і взаємин цієї держави хрестоносців 3 правителями і населенням середньовічної України. У сучасній українській історіографії деякі аспекти проблеми знахідок монет держави Тевтонського ордену в Пруссії на території України відображені в працях Г. Івакіна ${ }^{4}$, А. Позіховського та Р. Шуста ${ }^{5}$, С. Демидко, О. Погорільця і С. Стопенчука ${ }^{6}$, А. Шестопала ${ }^{7}$, Р. Саввова ${ }^{8}$, В. Орлика ${ }^{9}$ та ін. Окрім згаданих праць

${ }^{1}$ Котляр М. Ф. Грошовий обіг на території України доби феодалізму. К.: Наук. думка, 1971. - С.65

2 Страшкевич К. Клады, рассмотренные в минц-кабинете университета св. Владимира с 1818 по 1866 гг. Университетские известия. К., 1866. №10. С. 1-38.

3 Сецинский Е. Археологическая карта Подольской губернии, с картой, 3 таблицами планов городищ, указателем географических имен и предметным указателем. Труды одиннадцатого археологического съезда в Киеве в 1899 году. Москва: Тип. Г. Лисснера и А. Гешеля. Т. 1. С. 291.

${ }^{4}$ Івакін Г. Ю. Історичний розвиток Києва XIII - середини XVI ст. (історико-топографічні нариси). К., 1996. 272 с.

${ }^{5}$ Позіховський О., Шуст Р. Грошовий обіг на Волині в XIV - XVII століттях (За матеріалами монетних скарбів у фондах Державного історико-культурного заповідника міста Острог Рівненської області) (Додаток. Опис скарбів). Вісник Львівського університету: Серія історична. Львів: Видавництво ЛНУ ім. І. Франка, 2005. Вип. 39-40. С. 543.

${ }^{6}$ Демидко С., Погорілець О., Стопенчук С. Дослідження залишків пізньосередньовічного укріплення XVI ст. поблизу смт/ Меджибіж Летичівського р-ну Хмельницької обл. Археологічні дослідження в Україні 2004-2005 pp. КиївЗапоріжжя, 2006. С 8-10.

${ }^{7}$ Шестопал А. В. Скарби Черкащини. Черкаси: Вид. Андрощук П. С., 2007. 120 с.

${ }^{8}$ Саввов Р. Подольский полугрошек и денежное обращение в Подольском княжестве. Банкаўскі веснік, 2016. №3 (632), C. 16.

9 Орлик В. Знахідки на Волині монет банату Северин із символікою Тевтонського ордену. Актуальні проблеми нумізматики у системі спеціальних галузей історичної науки: тези доп. III-ї міжнар. наук.-практ. конф, 5-6 листопада 2015 р. Кіровоград-Київ-Переяслав-Хмельницький, 2015. С. 46-47; Его же. Монеты государства Тевтонского ордена в Пруссии в составе денежных и денежно-вещевых кладов, найденных на территории Украины. Наукові записки 3 української історії: Зб. наук. ст. Переяслав-Хмельницький, 2013. Вип. 33. С. 39-45; Його ж. Обрізаний шилінг магістра Тевтонського ордену Міхаеля Кюхмейстер фон Штернберга знайдений на Львівщині / Василь Михайлович Орлик. // Актуальні проблеми нумізматики у системі спеціальних галузей історичної науки: тези доповідей IV-ї міжнародної науково-практичної конференції, 22-23 червня 2016 р. - Кіровоград-Київ-Переяслав-Хмельницький, 2015. - С.54-56; Idem. A Coin Hoard of Pre-Reform Shillings of the Grand Master Michael Küchmeister von Sternberg Found in Chernihivschyna. Acta Archaeologica Lodziensia, 62, 2016. S. 93-97; Idem. . False Coins of the Teutonic Order State in 
дослідників, відомості про знахідки в Україні монет держави Тевтонського ордену в Пруссії містяться у різнопланових джерелах: архівних документах, музейних колекціях, свідченнях краєзнавців та матеріалах форумів скарбошукачів ${ }^{1}$. Щодо останніх, то необхідно зазначити, що розвиток в останні десятиліття приладового металопошуку та його застосування так званими «пошуковцями» або «скарбошукачами» при недостатній правовій захищеності археологічних пам'яток призводять до їхньої руйнації та «збільшення кількості археологічного матеріалу на колекційному «чорному» ринку» ${ }^{2}$. Проте учені без спеціальної державної підтримки, самостійно не в змозі вплинути на таке негативне явище, як несанкціоновані аматорські розкопки за допомогою спеціальних приладів металопошуку. Окрім цього, як зазначає сучасний російський учений археологічних об’єктів не в компетенції нумізматів, а от професійним їхнім обов'язком «є наукова фіксація всього доступного матеріалу»³. Тому ми цілком погоджуємося із тезою проф. В. П. Коцура, про те, що сучасні дослідники нумізматики, виходячи 3 реалій сьогодення, все ж вимушені шукати оптимальні шляхи отримання максимальної користі від матеріалів «чорної» археології для вітчизняної науки ${ }^{4}$. Зупинимося детальніше на усіх відомих нам знахідках на українських землях монет держави Тевтонського ордену в Пруссії, систематизуючи їх відповідно до адміністративно-територіального поділу України.

\section{Вінницька область}

У 2013 році в околицях с. Кузьмині Гайсинського району було виявлено монетний комплекс, до складу якого входило 47 монет XIV - початку XV ст., у тому числі й 1 шилінг держави Тевтонського ордену ${ }^{5}$. Скарб описаний і опублікований хмельницьким дослідником Р. Саввовим.

Чотирнадцятого квітня 2012 р. на березі р. Південний Буг, поблизу с. Іванів Калиновського району було знайдено шилінг Іоганна фон Тіфена (1489- 1497).

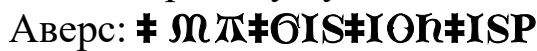

Реверс: $\uparrow \boldsymbol{M}$ On $\boldsymbol{\theta}<$... $>\mathbf{n}$ ORVM PR.

Монета була продана на аукціоні сайту «Віоліті» 18 квітня 2012 p.

Цей же респондент восени 2012 р., знайшов шилінг Пауля фон Русдорфа (1422 - 1441) на території Літинського району.

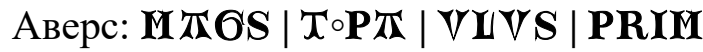

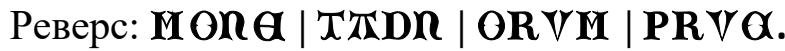

Prussia in the currency of South-Rus Lands of the Lithuanian Grand Duchy. Pieniadz i systemy monetarne wspolne dziedzictwo Europy. Studia i materialy. Augustow - Warszawa, 2012. S. 112-115; Idem. Rare variety of shilling of the Grand Master of the Teutonic Order Paul von Rusdorf found in volyn region, Forum Numizmatyczne: Peniadz i mennice, \#1, Bialystok, 2016, s. 10-14; Idem. Rzadki wariant szeląga Zakonu Krzyżackiego z Teofipolskiego skarbu. Biuletyn Numizmatyczny, 4 (388), 2017. S.258-263; Idem. Teutonic Order and the Battle on the Vorksla River in August, 1399 (Numismatic Aspect). Pieniadz a propaganda. Wspolne dziedzictwo Europy, Augustow-Warszawa, 2015. S. 100-104; Idem. Udział wojsk Zakonu Krzyżackiego w bitwie nad rzeką Worsklą w sierpniu 1399 r. w świetle źródeł numizmatycznych / Buletyn Numizmatyczny, Nr 3, 2015, s.175-180.

1 Орлик B. Інформаційний потенціал WEB-ресурсів у нумізматичних дослідженнях (на прикладі монет держав хрестоносців). Архівознавство та джерелознавчі галузі знань: проблеми взаємодії на сучасному етапі. Матеріали наук. конф. 3 міжнар. участю 14 березня 2013 р. К., 2013. - С 129-133.

2 Коцур В.П. Щодо проблеми використання матеріалів «чорної» археології в наукових дослідженнях з нумізматики / В.П. Коцур //Тези доповідей IV міжнародної науково-практичної конференції [«Актуальні проблеми нумізматики у системі спеціальних галузей історичної науки»] (22-23 червня 2016 р.). - Кіровоград - Київ - ПереяславХмельницький, 2016. - С.11 (11-14)

3 Гайдуков В.П. 700-летие российского рубля и краткий обзор развития средневековой русской нумизматики. Материалы Международной научной конференции [«Российский рубль. 700 лет истории»]. (25-27 апреля 2016 г., Великий Новгород). - Великий Новгород, 2017. - С.5-15.

${ }^{4}$ Kotsur V. Methodological issues of modern numismatic research: materials of "black" archeology and scientific research / Forum Numizmatyczne: Peniadz i mennice - \#1. - Bialystok, 2016. - S. 8. (7-9)

${ }^{5}$ Саввов Р. Подольский полугрошек и денежное обращение в Подольском княжестве. Банкаўскі веснік, 2016. №3 (632). C. 16 . 
Даний тип монети описаний видатним німецьким нумізматом і сфрагістом XIX ст. Ф.-А. Фоссбергом під № $829^{1}$. Обставини знахідки та її подальша доля нам невідомі.

У 2002 р. в Немирівському районі, за свідченням київського колекціонера Вадима Сироти, було знайдено грошовий комплекс, ймовірно, загублений гаманець. До його складу входило 19 монет: 11 монет Золотої Орди, вроцлавський гріш часів Матвія Корвіна (Матяша Гуняді), 6 празьких грошей Вацлава II та шилінг Генріха Реффле фон Ріхтенберга (1470 - 1477). Обставини знахідки та подальша доля монет, які входили до даного грошового комплексу, нам невідомі.

Два пореформені шилінги Міхаеля Кюхмейстера фон Штернберга (14141422), емісії 1416 - 1422 рр., за твердженням їхнього власника, були знайдені у вересні 2011 р. на полі між с. Сорокотяженці та с. Кірово Немирівського району.

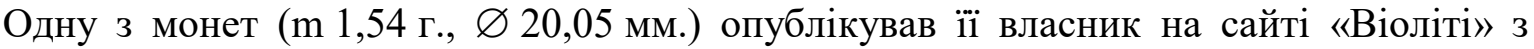
проханням визначити емітента та оцінити їі вартість.

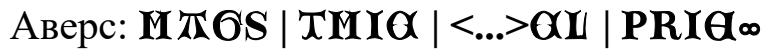

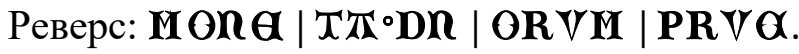

Дана монета продана на аукціоні сайту «Віоліті» 21.09.2011 p.

Восени 2016 р. на околицях смт. Брацлав Немирівського району був знайдений дореформений шилінг Міхаеля Кюхмейстера фон Штернберга (1414 1422) емісії $1414-1416 \mathrm{pp}$.

Навесні 2012 р. під час проведення робіт по догляду за садом на вулиці Леніна 60 в с. Лука-Барська, Барського району було виявлено грошовий скарб тривалого накопичення, загальна чисельність близько 4 тис. монет XV - початку XVII ст. До складу цього монетного комплексу входило й 16 монет Держави Тевтонського ордену в Пруссії:

- дореформений шилінг Міхаеля Кюхмейстера фон Штернберга (1414 1422) емісії $1414-1416$ pp.

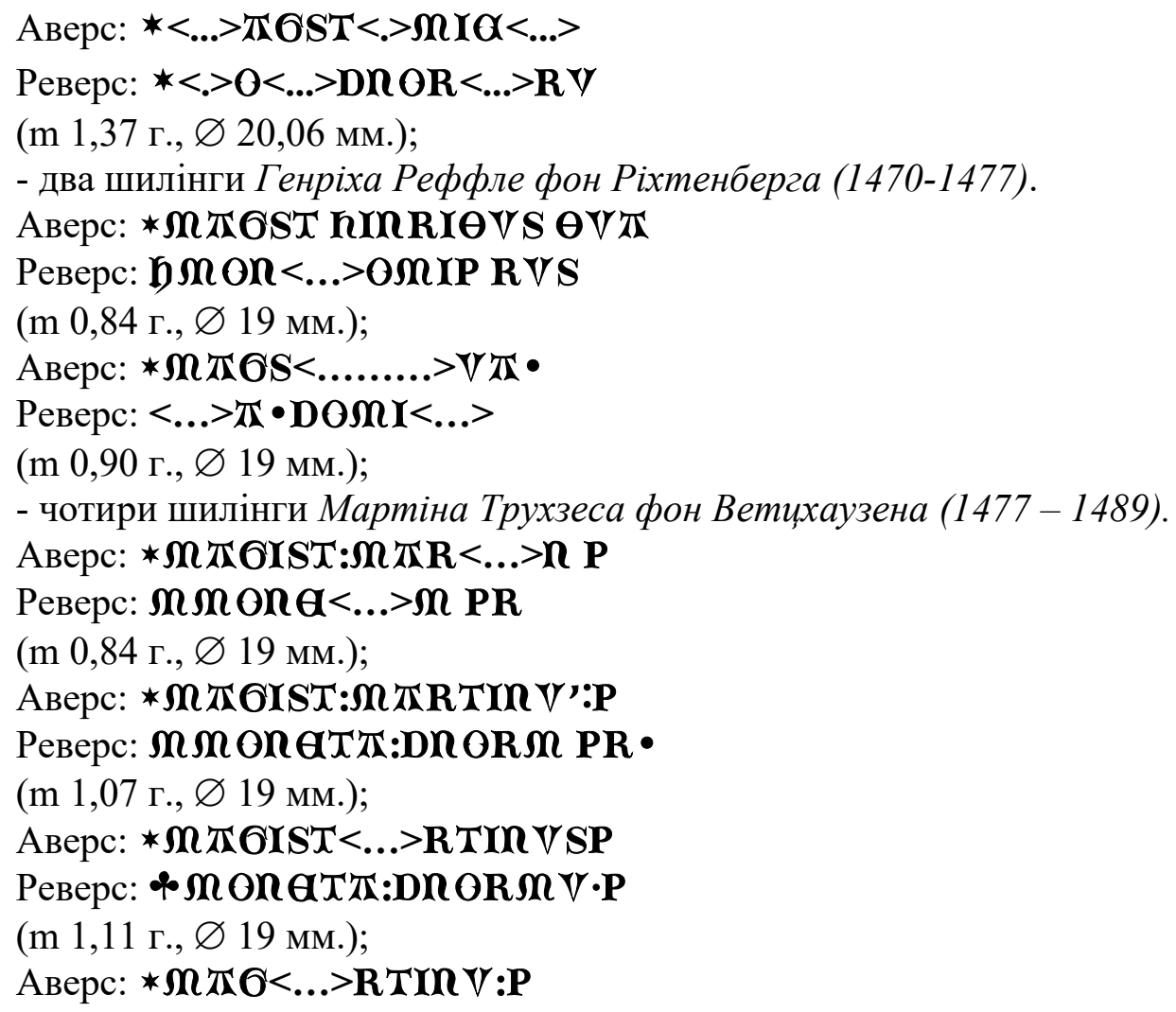

\footnotetext{
${ }^{1}$ Voßberg, Friedrich August, Geschichte der preußischen Münzen und Siegel von frühester Zeit bis zum Ende der Herrschaft des Deutschen Ordens. - Berlin, 1843. - S.163.
} 


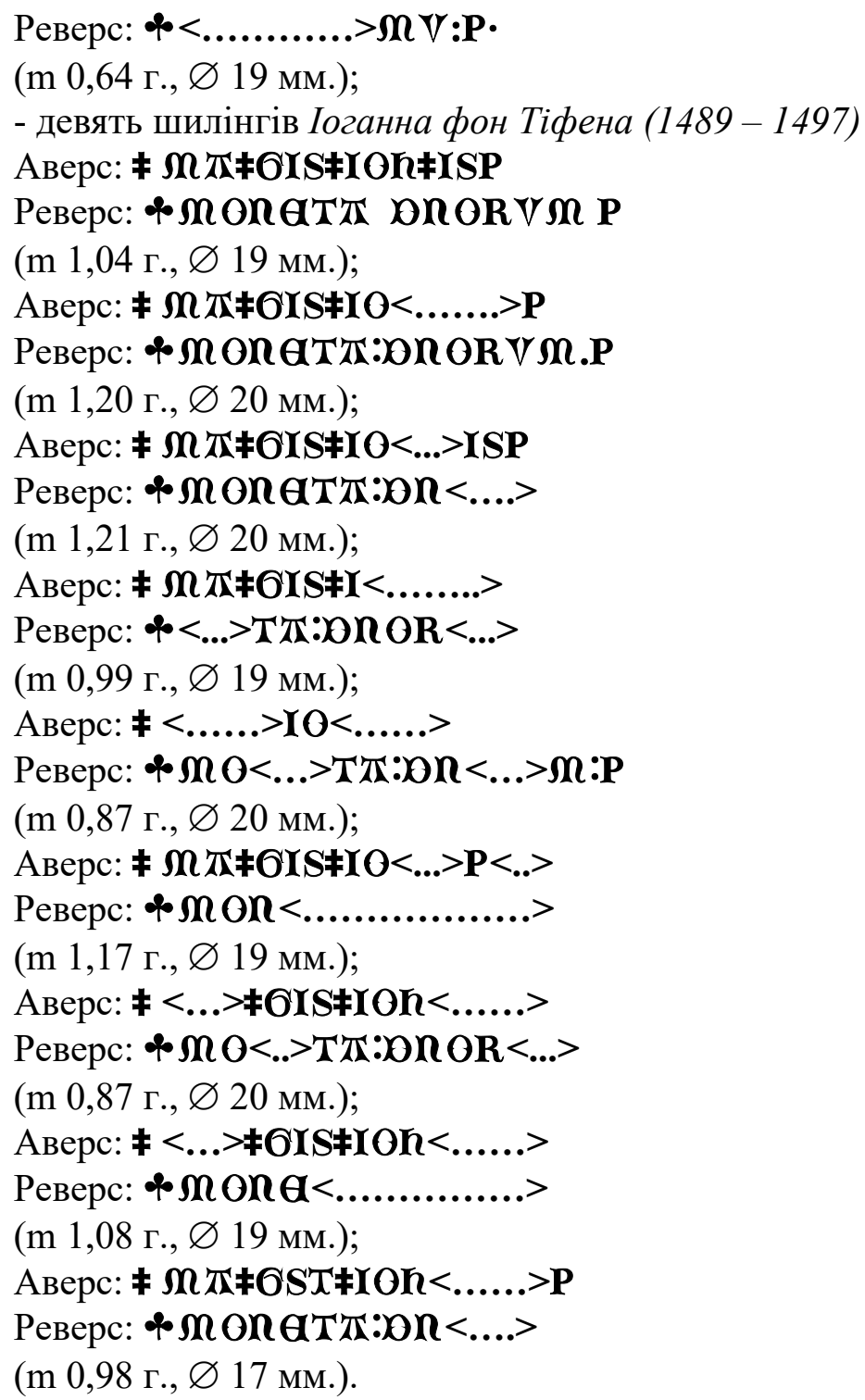

Частина знайдених монет Тевтонського ордену сильно зношені, на деяких легенди практично не залишилося. Саме тому були допущені певні неточності при нашому попередньому частковому описі частини даного монетного комплексу ${ }^{1}$. Після особистого детального ознайомлення із цією частиною скарбу нами були внесені певні корективи до його опису, які публікуються вперше.

У с. Козинці Тростянецького району (раніш Брацлавського повіту Подільської губернії) у 1844 р. був знайдений скарб до складу якого входили 2 монети держави Тевтонського ордену в Пруссії, зокрема шилінг Генріха Ройсса фон Плауена (адміністратора ордену) (1467 - 1469) та шилінг Генріха Рефрдле фон Ріхтенберга (1470 - 1477). Скарб описаний завідувачем мюнц-кабінету університету св. Володимира (тепер Київський національний університет імені Тараса Шевченка) Кіндратієм Страшкевичем, де ці монети зберігалися² .

У травні 2015 р. на межі Погребищенського та Козятинського районів Вінницької області, за повідомленням місцевого любителя приладового металопошуку, було знайдено шилінг Пауля фон Русдорфа (1422 - 1441).

\footnotetext{
${ }^{1}$ Орлик В. Монеты государства Тевтонского ордена в Пруссии... - С.41.

${ }^{2}$ Страшкевич К. Указ. соч.-С. 16.
} 
Обставини знахідки та їі подальша доля нам невідомі.

У межах Тульчинського району був знайдений шилінг Пауля фон Русдорфа $(1422-1441)$.

Аверс: MTGS|T・PT|VIVSS|PRIM

Реверс: M OIG|TRDR|OR VM|PRVG.

Ця монета відповідає типу монет Держави Тевтонського ордену в Пруссії описаним Ф.-А. Фоссбергом під № 821 ${ }^{1}$. Час та обставини знахідки нам невідомі. Монета була продана на аукціоні сайту «Віоліті» 07.03 .2016 р. за 400 грн.

У 2013 р. поблизу с. Уланів Хмільницького району був знайдений шилінг Пауля фон Русдорфа (1422-1441).

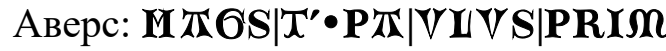

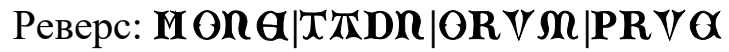

(m 1,20 г.).

Даний шилінг відповідає типу монет держави Тевтонського ордену в Пруссії, описаному Ф.-А. Фоссббергом під № $850^{2}$.

Обставини знахідки та ііі подальша доля нам невідомі.

У вересні 2015 р. поблизу м. Хмільник був знайдений шилінг Мартіна Трухзеса фон Ветихаузена (1477-1489).

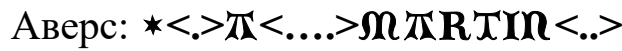

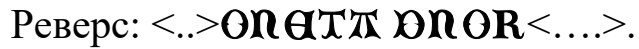

Час, обставини знахідки та ії подальша доля нам невідомі.

Також на теренах сучасної Вінниччини в різні часи були знайдені й інші монети Тевтонського ордену. Зокрема, дореформений шилінг (m 1,17 г., Ø 20 мм.) Міхаеля Кюхмейстера фон Штернберга (1414 - 1422). емісії 1414 - 1416 pр.

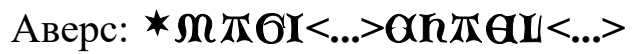

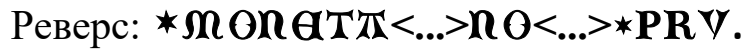

Час, район та обставини знахідки нам невідомі. Монета продана на аукціоні сайту «Віоліті» 27.12.2010 р. за 110 грн.

Шилінг Іоганна фон Тіфена (1489 - 1497).

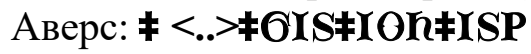

Реверс: $\bullet<. .>\pi$ DNORVM $\cdot \mathbf{P}$.

Час та обставини знахідки нам невідомі. Монета продана на аукціоні сайту «Віоліті» 16.02.2011 p.

У червні 2015 р. на Інтернет-аукціоні «Віоліті» був проданий шилінг магістра Генріха Реффле фон Ріхтенберга (1470 - 1477).

Аверс: *Mr ToISTAR:hInRIOV.

Реверс: $\mathbf{n} \circ \mathbf{M}$ ONAT $<\ldots . .>\mathbf{D O M I}^{\circ} \mathbf{P} .^{\circ}$

Даний шилінг відповідає типу монет, описаному Ф.-А. Фоссбергом під № $947^{3}$. Монета знайдена у Вінницькій області. Час, обставини знахідки та іiі подальша доля нам невідомі.

У червні 2015 р. на Інтернет-аукціоні «Віоліті» був проданий шилінг магістра Іоганна фон Тіфена (1489 - 1497). За відомостями, наданими нам власником монети, вона була знайдена ним у червні 2015 р. за 20 км на південь від м. Вінниця.

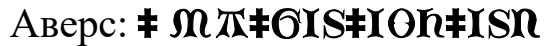

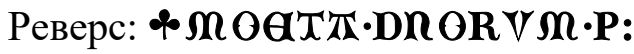

Ця монета відповідає типу монет, описаному Ф.-А. Фоссбергом під № $1087^{4}$.

Час, обставини знахідки та ії подальша доля нам не відомі.

\footnotetext{
${ }^{1}$ Voßberg F. A. Op. cit.- S.183.

Ibid.- S.164.

${ }^{3}$ Ibid.- S.181.

${ }^{4}$ Ibid. - S.189.
} 
The Ukrainian Numismatic Annual, Issue 1.

У травні 2015 р. на території Вінницької області був знайдений сильно затертий шилінг магістра Іоганна фон Тіфена (1489-1497). Час і обставини знахідки та подальша доля монети нам невідомі.

У березні 2016 р. був знайдений пореформений шилінг часів великого магістра Людвіга фон Ерліхсхаузена (Елльріхсхаузена) (1450 - 1467).

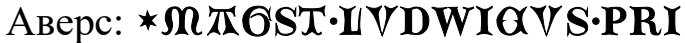

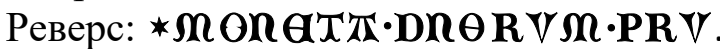

Монета відповідає типу, описаному Ф.-А. Фоссбергом під № $893^{1}$. Монета опублікована їі власником на українському сайті «Віоліті» 3 проханням визначити емітента та оцінити iï вартість ${ }^{2}$. Нам невідомі час, обставини та місце їі знахідки, власник монети лише вказав, що вона були знайдена поблизу с. Лисогірка, які у Вінницькій області $є$ в Жмеринському, Літинському та Хмільницькому районах. Даний шилінг був проданий на аукціоні Інтернет-форуму «Віоліті» 14.05.2016 p.

\section{Волинська область}

Весною 2009 р. в урочищі Старе Село понад р. Лугою, поблизу с. Житані Володимир-Волинського району, було знайдено частину монети Держави Тевтонського ордену в Пруссії. На аверсі даного фрагменту монети збереглася верхня частина гербового щита великого магістра, зокрема геральдичний щит із орлом та частина кругової легенди. На реверсі - гербовий щит Ордену з хрестом, та частина кругової легенди.

Аверс: MTOS $|\pi<\ldots \ldots . .>S|$ PRYM

Реверс: <........> | ORVM | PRVS.

Весною 2010 р. поблизу м. Володимира-Волинського було знайдено шилінг Генріха Ройсса фон Плауена як адміністратора Держави Тевтонського ордену в Пруссії (1467 - 1469).

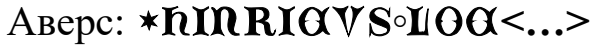

Реверс: $\rightarrow \mathbf{M}$ OR<...>ORVM 。PRV.

Монета знаходиться в приватній колекції.

У листопаді 2010 р. поблизу м. Володимира-Волинського було знайдено шилінг Конрада фон Ерліхсхаузена (Елльріхсхаузена) (1441 - 1449).

Аверс: <...> $|T<.>\alpha O<.>| \pi D V S \mid$ GVIn

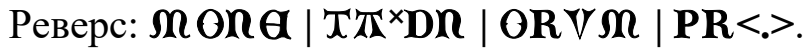

Монета продана на аукціоні сайту «Віоліті» 06.12.2010 p.

Того ж року за 3 км. від м. Володимира-Волинського було знайдено шилінг Мартіна Трухзеса фон Ветихаузена (1477-1489).

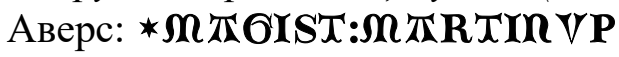

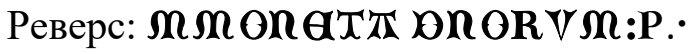

Монета знаходиться в приватній колекції.

У жовтні 2011 р. в околицях м. Володимира-Волинського був знайдений шилінг Мартіна Трухзеса фон Ветихаузена (1477 - 1489).

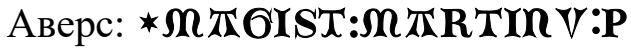

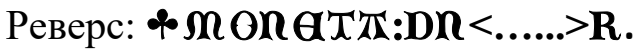

Монета опублікована власником під час спроби іiі продажу на аукціоні сайту «Віоліті» 09.03.2012 р. разом із шелягом, карбованим у м. Гданську від імені Казимира Ягеллона.

У грудні 2011 р. поблизу м. Володимир-Волинський (місцеве населення цей район називає «Глибока балка») був знайдений дореформений шилінг (m 1,37 г.,

\footnotetext{
${ }^{1}$ Ibid. - S.173.

2 Violity. - Монета на определение (Польша или Литва) [Електронний ресурс]. - Режим доступу: http://forum.violity.com/viewtopic.php?t=1513819\&highlight/. - Назва з екрана. (28.09.2016)
} 
Украӥнський нумізматичний щорічник. Вип. 1.

$\varnothing$ 20,06 мм.) Міхаеля Кюхмейстера фон Штернберга (1414-1422) емісії 1414 1416 pp. На монеті $є$ чіткий слід від перегинання. Власником нам була надана фотографія аверсу цього шилінга та його метрологічні характеристики.

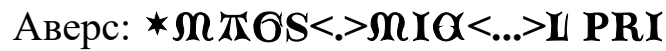

(m 1,07 г., Ø 22 мм.).

Власник монети зазначив, що на місці їі знахідки зустрічаються й інші середньовічні монети та середньовічна кераміка.

На околиці с. Черничі Володимир-Волинського району, біля р. Луга, був знайдений шилінг Мартіна Трухзеса фон Ветихаузена (1477 - 1489).

Аверс: *<...>ST:M正RTI<...>

Реверс: $\bullet$ M ONGT<...>ORVMP.

Час знахідки та подальша доля монети автору невідомі.

У цьому ж селі було знайдено фальсифікат гроша Іоганна фон Тіфена (1489 1497).

Аверс: MTOS $|T \cdot \mathbf{I O}<\ldots>|$ IFOn

Реверс: HOR <............... $>$ RVS

(m 2,03 г., $\varnothing 18,5$ мм.).

Монета знаходиться у приватній колекції. Монета опублікована нами у статті, присвяченій проблемам фальшивомонетництва в державі Тевтонського ордену в Пруссії ${ }^{1}$.

У травні 2011 р. на території Володимир-Волинського району був знайдений шилінг Іоганна фон Тіфена (1489-1497).

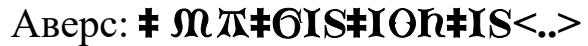

Реверс: ^ m On

Монета продана на аукціоні сайту «Віоліті» 20.05.2011 p.

Біля с. Хотячів Володимир-Волинського району, у 2011 р. був знайдений гріш (m 1,34 г., Ø 19 мм.) Іоганна фон Тіфена (1489 - 1497).

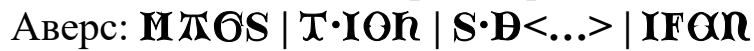

Реверс: HOR $\boldsymbol{\alpha}|\boldsymbol{\pi} \pi<\ldots>|$ ORVH $\mid$ PRVS.

Монета знаходиться в приватній колекції.

Восени 2011 р. поблизу с. Красностав Володимир-Волинського району був знайдений шилінг Іоганна фон Тіфена (1489-1497).

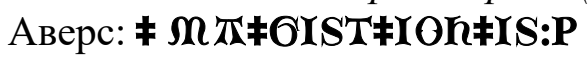

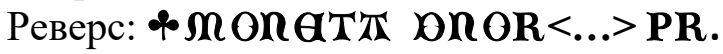

Монета продана на аукціоні сайту «Віоліті» 11.02.2012 p.

У жовтні 2011 р. на відстані близько 10 км. від. м. Володимира-Волинського було знайдено односторонню срібну монету (брактеат) типу «Хрест грецький III» (Рис.2) емісії 1416 - 1460 pp. $^{2}$ Монета продана на аукціоні сайту «Віоліті» 09.11.2012 p.

Десятого вересня 2012 р. в с. Заріччя Володимир-Волинського району був знайдений шилінг Іоганна фон Тіфена (1489-1497).

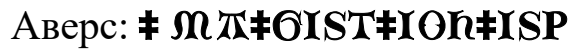

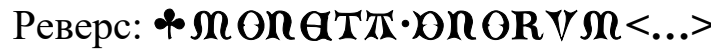

( $\varnothing 20,0$ мм.).

Монета опублікована для ідентифікації іiі власником на форумі сайту «Віоліті». Подальша доля монети нам невідома.

У межах м. Володимир-Волинський був знайдений шилінг Мартіна Трухзеса фон Ветихаузена $(1477-1489)$.

\footnotetext{
${ }^{1}$ Orlyk V. False Coins of the Teutonic Order State in Prussia... - S.112-115

${ }^{2}$ Paszkiewicz B. Brakteaty - pieniądz średniowiecznych Prus. - Wroclaw, 2009. - Tab.X.
} 


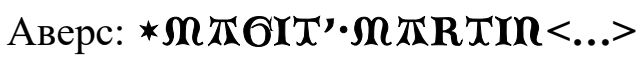

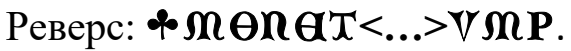

Час і обставини знахідки нам не відомі.

Поблизу с. Ізов Володимир-Волинського району був знайдений шилінг Мартіна Трухзеса фон Ветихаузена (1477-1489).

Аверс: *<...>MRRTIMV $V<\ldots>$

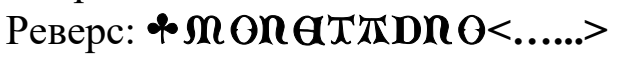

Час і обставини знахідки нам невідомі. Монета опублікована власником під час іiї продажу на аукціоні сайту «Віоліті».

У липні 2016 р. на полі, розташованому на березі річки Липа в Горохівському районі, за 10 км. від м. Берестечко, був знайдений шилінг Пауля фон Русдорфа (1422 $-1441)$.

Аверс: HA GS | T'”PA | VUVS | PRIM

Реверс: HONA | TARDR | ORVM | PRV $\boldsymbol{\alpha}$

(m 1,46 г., Ø 21 мм.).

Обставини знахідки нам невідомі. Монета відповідає шилінгу, описаному Ф.-А. Фоссбергом під №837¹ . Монета опублікована нами․

У листопаді 2010 р. в районі с. Заставне Іваничівського району було знайдено «гаманець» із 4 монет Держави Тевтонського ордену в Пруссії. Зокрема, шилінги Генріха Ройсса фон Плауена як адміністратора (1467 - 1469).

Аверс: *hIn<...>VTARAS $\mathbf{M}$

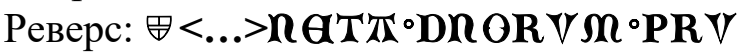

та Іоганна фон Тіфена (1489-1497).

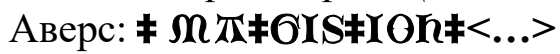

Реверс: $\bullet<. . .>\alpha$ OR PRV.

Ці дві монети були продані на аукціоні сайту «Віоліті», перша - 26.03.2011 p., а друга - 14.10.2010 р. Окрім указаних шилінгів, в даному монетному комплексі були ще дві неідентифіковані монети Держави Тевтонського ордену в Пруссії.

У березні 2011 р. в с. Жашковичі Іваничівського району був випадково знайдений гріш-кліппа останнього правителя Держави Тевтонського ордену в Пруссії Альбрехта фон Бранденбург-Ансбах (1510 - 1325), обрізаний під круглу монету (m 0,4 г., $\varnothing 13,5$ мм). Подальша доля монети невідома.

Влітку 2011 р. поблизу с. Самоволя Іваничівського району був знайдений шилінг Тевтонського ордену. Магістр, монетний двір та подальша доля монети нам невідомі.

У жовтні 2011 р. поблизу с. Литовеж Іваничівського району був знайдений сильно затертий шилінг. Аналіз іконографії та залишків легенди на монеті дозволяють віднести іiі емісії великого магістра Мартіна Трухзеса фон Ветихаузена $(1477-1489)$.

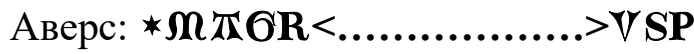

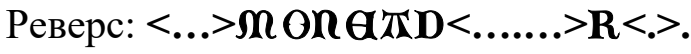

Цей шилінг доданий у якості бонуса під час продажу 12.02.2012 p. на аукціоні сайту «Віоліті» полугроша Сигизмунда Старого, м.д. Краків.

У червні 2012 р. на форумі сайту «Віоліті» було виставлено 5 монет 3 проханням визначити їхніх емітенів та оцінити їхню вартість. Серед виставлених монет був шилінг Іоганна фон Тіфена (1489 - 1497).

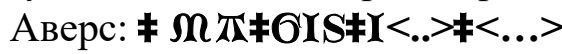

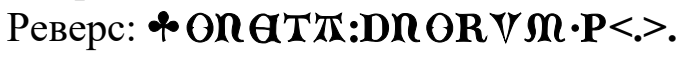

\footnotetext{
${ }^{1}$ Voßberg F. A. Op. cit. - S.163.

${ }^{2}$ Orlyk V. Rare variety of shilling... - S.10-14.
} 
За словами власника монети, вона була знайдена ним у травні 2012 р. поблизу с. Литовеж Іваничівського району. Подальша доля монети невідома.

Весною 2013 р. за 5 км. від смт. Іваничі поблизу р. Луга був знайдений гріш Іоганна фон Тіфена (1489-1497).

Аверс: $\mathbf{M} \pi \mathbf{T} \mathbf{O S}|\mathrm{T} \cdot \mathbf{I O h \mathbf { R }}| \mathbf{S} \cdot \boldsymbol{\theta \Theta} \cdot \mathbf{T} \mid \mathbf{I F O M I}$

Реверс: $\mathbf{M}$ On $\mathbf{A} \mid \pi \pi \cdot \boldsymbol{\theta} \mathbf{R}$ | ORVM | PRVS.

Монета була опублікована тї власником на сайті «Віоліті» 05.08.2013 p. 3 проханням визначити магістра Ордену та оцінити іiї вартість. Подальша доля монети нам невідома.

У листопаді 2015 р. в межах с. Колона Іваничівського району був знайдений пореформений шилінг Міхаеля Кюхмейстера фон Штернберга (1414 - 1422) емісії $1416-1422 \mathrm{pp}$.

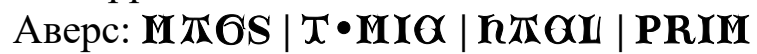

Реверс: MORA|Tт・DR | ORVM | PRVM.

Даний тип монет описаний сучасними польськими дослідникам Ярославом Дутковські та Адамом Сушанеком під №775-776². Зображення монети було опубліковано ії власником на аукціоні «Віоліті» під час спроби іiї продажу у грудні 2015 р. Обставини знахідки та подальша доля монети нам невідомі.

У січні 2015 р. неподалік від м. Ковель був знайдений дореформений шилінг Міхаеля Кюхмейстера фон Штернберга (1414 - 1422) емісії 1414 - 1416 рр.

У вересні 2009 р. поблизу смт. Локачі, Локачинського району був знайдений шилінг Іоганна фон Тіфена (1489 - 1497).

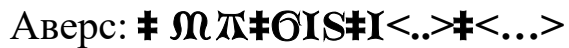

Реверс: \& $\mathbf{m}$ On<...>DNORVM PRV.

У серпні 2010 р. в межах с. Хорів Локачинського району був знайдений надламаний шилінг Іоганна фон Тіфена (1489-1497).

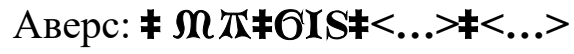

Реверс: $\bullet<. . .>$ Tत DNO<...>

(m 0,72 г., Ø 19 мм.).

Монета опублікована іï власником на українському сайті «Віоліті» 3 проханням визначити емітента та оцінити іiі вартість. Монета знаходиться в приватній колекції.

На околицях смт. Локачі Локачинського району в 2016 р. був знайдений грош Іоганна фон Тіфена (1489 - 1497). Монета була зігнута навпіл.

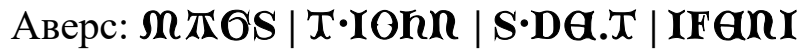

Реверс: $\mathbf{M}$ OR $\boldsymbol{A}|\mathrm{T} \pi \cdot \mathbf{D R}|$ OR VM | PRVS:

(m 1,12 г., Ø 21 мм.).

Час та обставини знахідки нам не відомі. Монета була продана на аукціоні Інтернет-ресурсу «Віоліті» 2 жовтня 2016 р.

Восени 2011 р. за 5 км. по течії р. Стир від с. Маяки Луцького району було знайдено затертий продірявлений шилінг Тевтонського ордену. Іконографія та залишки легенди на монеті дають підстави віднести його до емісії великого магістра Людвіга фон Ерліхсхаузен (Елльріхсхаузена) (1450-1467), м.д. м. Кенігсберг.

Аверс: $<. . .>$ T $O S T<\ldots>$ W $<$.. $>$ OVVS P $<\ldots>$

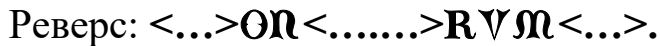

Монета опублікована 26.05.2012 p. iï власником на українському сайті «Віоліті» 3 проханням визначити емітента та оцінити іiі вартість. Подальша доля монети невідома.

\footnotetext{
${ }^{1}$ Dutkowski Jaroslaw, Suchanek Adam. Corpvs Nvmmorvm Civitatis Thorunensis. - Gdansk: Drukarnia PROMA, 2010. - S.79. -\# 775-776
} 
У жовтні 2011 р. поблизу м. Луцька, на місці літньої резиденції єпископа, був знайдений пені (pfennings) Лівонського ордену м.д. м. Ревель. За класифікацією сучасного естонського дослідника Г. Хальяка монета подібна до типу Т-2 №45른, емісії 1398 - 1403 pp. і має ступінь рідкості R.

\section{Аверс: RGVArIG}

Реверс: RGVAria

(m 0,29 г., Ø 12,5 мм.).

Монета була опублікована луцьким любителем приладового металопошуку 02.11.2011 р. на сайті «Віоліті» для іїі ідентифікації, а 21.01.2012 р. продана луцькому колекціонеру на аукціоні «Віоліті».

У травні 2002 р., в м. Луцьк, за свідченням київського історика Вадима Сироти, було знайдено шилінг Пауля фон Русдорфа (1422 - 1441). Час, обставини знахідки та ії подальша доля нам невідомі.

У грудні 2011 р. на околиці м. Луцька був знайдений фальсифікат шилінга Пауля фон Русдорфа (1422 - 1441).

Аверс: M公OS $|\boldsymbol{T}: \mathbf{P} \pi|<\ldots>\mathbf{S}$

Реверс: <...>A | Tत्TDR | ORVM | PRVS

(m 1,01 г., Ø 21 мм.). нами ${ }^{2}$.

Монета знаходиться в приватній колекції, іiі опис та зображення опубліковані

У 2016 р. на околицях м. Луцька був знайдений сильно затертий шилінг Генріха Реффле фон Ріхтенберга (1470 - 1477).

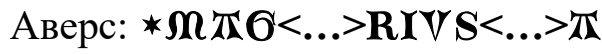

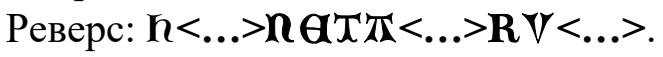

Час та обставини знахідки нам невідомі. Монета була продана на аукціоні Інтернет-форуму «Віоліті» 3 жовтня 2016 p.

У басейні р. Стир поблизу с. Маяки Луцького району наприкінці квітня 2012 р. був знайдений фальшак гроша Іоганна фон Тіфена (1489 - 1497).

Аверс: MTOS |TIOHR |SDGT|IFGRI

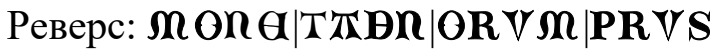

(m 1,28 г., Ø 20 мм.). нами ${ }^{3}$.

Монета знаходиться в приватній колекції, іiі опис та зображення опубліковані

Весною 2013 р. поблизу с. Крупа Луцького району був знайдений обломок шилінга Пауля фон Русдорфа (1422 - 1441). На уцілілому фрагменті монети $є$ залишки легенди, які дозволили нам ії ідентифікувати.

Аверс: $<\ldots . .>|<\ldots . .>|<.>\mathbf{V} \mathbf{V}<.>\mid<\ldots>\mathbf{I M}$

Реверс: $\mathbf{M}<. . .>\mid$ Tर $<$ <.. $>|<\ldots>|$ PR $\boldsymbol{V} \boldsymbol{\alpha}$.

Даний фрагмент шилінга був проданий на аукціоні «Віоліті» в лоті поламаних срібних монет загальною масою на 45 грн.

У вересні 2016 р. на полі поблизу смт. Рокині Луцького району був знайдений затертий пенні початку XV ст. м.д. Тарту (Дерпт). Монета належить до єпископських емісій Лівонії. Як відомо, у підпорядкуванні Дерптського єпископства перебувала й частина земель Лівонського ордену. На обох боках монети у внутрішньому колі - герб капітулу Дерптського єпископства - схрещені ключ і меч, які були атрибутами апостолів Павла й Петра, котрі вважалися патронами Дерптського єпископства ${ }^{4}$. У зовнішньому колі монет містяться залишки легенди.

\footnotetext{
${ }^{1}$ Haljak G. Livonian Coins XIII-XVIII Century. Part I: Feudal States. Livonian Coins From XIII-XVI Century. - Tallinn, 2010. - P.83.

${ }^{2}$ Orlyk V. False Coins... - S.112-115.

${ }^{3}$ Ibid. - S.112-115.

${ }^{4}$ Федоров Д. Монеты Прибалтики XIII-XVIII столетий. Определитель монет. - Таллин, 1966. - C.22.
} 
Аверс: $<. .>\mathbf{D} \pi \mathbf{T} \mathbf{R} \boldsymbol{T M T}^{\circ} \boldsymbol{U}<. .>$

Реверс: $<$. $>$ T $<$.. $>$ On $\boldsymbol{A}<$. $>>$ D

(m 0,4 г., $\varnothing 15$ мм.).

Даної монети немає ні в каталозі Д. Федорова ${ }^{1}$, ні в каталогах Г. Хальяка ${ }^{2}$, на ній відсутній родинний знак єпископа. Враховуючи іконографію монети, можна припустити, що це емісія першої чверті XV ст. Подібні монети класифікуються Г. Хальяком як типи Т-2, Т-4, Т-5 і можуть належати до випусків монет часів єпископів Генріха III Врангеля (Heinrich III Wrangel) 1400-1410 pp., Бернхарда III Бюлова (Bernhard III Bülow) 1410 - 1413 pp. або емісії Дітриха IV Реслера (Dietrich IV Resler) 1413 - 1441 pр. до грошової реформи 1422 - 1424 pp. Монета була продана на аукціоні Інтернет-ресурсу «Віоліті» 19 вересня 2016 р.

На початку літа 2009 р. в Любомльському районі, поблизу с. Римачі за 2 км. від р. Західний Буг, було знайдено пореформений шилінг Людвіга фон Ерліхсхаузена (Елльріхсхаузена) (1450 - 1467), м.д. м. Кенігсберг.

Монета опублікована іï власником на українському сайті «Віоліті» 3 проханням визначити емітента та оцінити ії вартість.

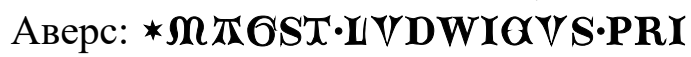

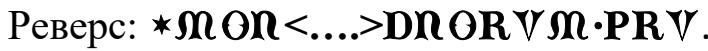

Подальша доля монети нам невідома.

Весною 2008 р. в Рожищенському районі був знайдений шилінг Пауля фон Русдорфа $(1422-1441)$.

Аверс: <..>OS | T०P农 | VIVVS | PRI<.>

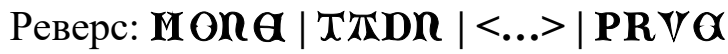

Монета зберігається в приватній колекції.

Влітку 2011 р. в озері Домашнє, с. Кримне Старовижівського району був знайдений грош Іоганна фон Тіфена (1489-1497).

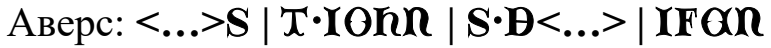

Реверс: $\mathbf{M}$ On $\boldsymbol{\alpha}|\mathrm{T} \pi<\ldots>|$ ORVH $\mid$ PRVS.

Подальша доля монети невідома.

У червні 2012 р. поблизу с. Буцин Старовижівського району був знайдений шилінг Генріха Реффле фон Ріхтенберга (1470 - 1477).

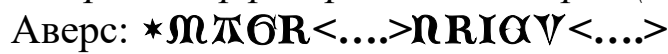

Реверс: $<$...> TRDO<....>PR $V<$. $>$.

Монета опублікована іï власником на українському сайті «Віоліті» 3 проханням визначити іiі тип. Подальша їі доля нам невідома.

У 1991 р. в смт. Турійськ було знайдено монетний скарб, до складу якого, за свідченнями очевидців, входило більше 1000 монет. Київському історику й колекціонеру Вадиму Сироті вдалося ознайомитися лише із 176 монетами 3 даного комплексу. Самою молодою монетою серед цих монет був коронний гріш польського короля Сигізмунда III 1629 р. Серед досліджених ним 176 монет було й 2 монети держави Тевтонського ордену в Пруссії, зокрема шилінг Пауля фон Русдорфа (1422 - 1441) та гріш Фрідріха фон Заксена (1498 - 1510).

У листопаді 2010 р. в Турійському районі, поблизу річки Турія, місцевим любителем приладового металопошуку було виявлено пореформений шилінг Міхаеля Кюхмейстера фон Штернберга (1414 - 1422).

Аверс: MTOS | TMIO $\mid \mathbf{n} \pi<$.. $>$ | PRIM

Реверс: M OR $\boldsymbol{\theta}|<. . .>|<.>V \mathbf{M} \mid \mathbf{P R V} \boldsymbol{\alpha}$.

Монета продана на аукціоні сайту «Віоліті» 29.11.2010 p.

\footnotetext{
${ }^{1}$ Федоров Д. Монеты Прибалтики XIII-XVIII столетий. Определитель монет. - Таллин, 1966. - 423 с.

${ }^{2}$ Haljak G. Liivimaa seestlingud, lübisched ja pennid XIII-XVI sajand. - Tallinn, 2007. - 108 s.; Idem. Livonian Coins XIIIXVIII Century. Part I: Feudal States. Livonian Coins From XIII-XVI Century. - Tallinn, 2010. - 399 p.
} 
У 2016 р. на території Шацького району був знайдений пореформений шилінг Міхаеля Кюхмейстера фон Штернберга (1414 - 1422).

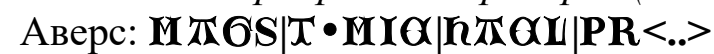

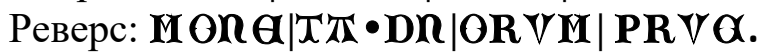

Монета продана на аукціоні сайту «Віоліті» 19.06.2016 р. за 200 грн. Даний тип монети описаний Ф.-А. Фоссбергом під № $811^{1}$.

Наприкінці 80-х років XX ст. на території Волинської області був знайдений скарб, який містив більше 5000 монет дрібних номіналів, у тому числі й близько 30 сильно затертих шилінгів великих магістрів держави Тевтонського ордену в Пруссії Мартіна Трухзеса фон Ветихаузена (1477 - 1489) та Іоганна фон Тіфена (1489 1497). Враховуючи час знахідки, його новий господар склав монети до скрині і не афішував його. Лише після смерті господаря онуки розпродали даний скарб. 3 частиною скарбу мав змогу ознайомитися львівський нумізмат Сергій Білопольський.

За свідченням одного із волинським любителів приладового металопошуку, у жовтні 2011 р. біля одного з городищ Волинської області ним було знайдено пореформений шилінг Міхаеля Кюхмейстера фон Штернберга (1414 - 1422), монетний двір м. Торунь, емісія 1416 - 1422 pp.

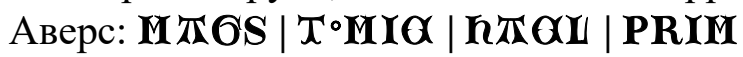

Реверс: MORA $\mid \pi \pi^{\circ}$ OR | ORVM | PRIM.

Монета опублікована іiі власником на українському сайті «Віоліті» 3 проханням визначити емітента та оцінити пї вартість. Обставини знахідки та подальша їі доля нам невідомі.

У межах Волинської області знайдено шилінг Генріха Реффле фон Ріхтенберг (1470 - 1477).

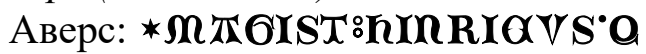

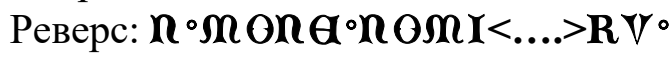

(m 0,74 г., Ø 20 мм.).

Монета знаходиться в приватній колекції.

У межах Волинської області знайдено шилінг Іоганна фон Тіфена (1489 1497). Час, місце, обставини знахідки та її подальша доля нам невідомі.

На території Волинської області було знайдено середньовічну підробку дореформеного шилінга Міхаеля Кюхмейстера фон Штернберга (1414 - 1422).

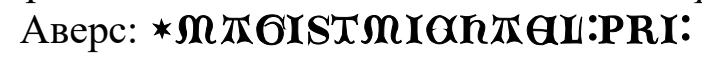

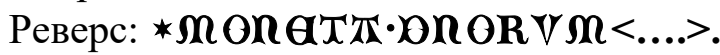

Час, місце та обставини знахідки нам невідомі. Монета зберігається у приватній колекції.

На теренах Волинської області, в басейні р. Луга в березні 2014 р. було знайдено пореформений шилінг Міхаеля Кюхмейстера фон Штернберга (1414 1422), емісія 1416 - 1422 pp.

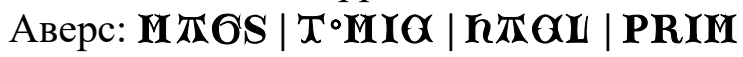

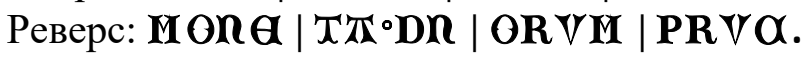

Монета опублікована iï власником на українському сайті «Віоліті» для ii атрибуції. Час, місце, обставини знахідки та її подальша доля нам невідомі.

У травні 2015 року на українському Інтернет-форумі «Віоліті» було виставлено на визначення дві білонові монети, на одному боці яких містилась символіка Тевтонського ордену, зокрема орденський хрест на щиті. Дані знахідки опубліковані нами й ідентифіковані як монети прикордонних територій Угорського королівства - банату Северин часів управління цим регіоном представниками

${ }^{1}$ Voßberg F. A. Op. cit. - S.160. 
держави Тевтонського ордену на чолі з Ніколау фон Редвітцом ${ }^{1}$. За свідченням власника, ці монети та дві монети емісій молдавського господаря Олександра Доброго (1400 - 1432 рр.) були випадково знайдені у Волинській області поблизу річки Луга.

\section{Житомирська область}

Восени 2005 р., за свідченням київського історика Вадима Сироти, на території Коростишівського району було знайдено шилінг Пауля фон Русдорфа $(1422$ - 1441). Монета має отвір. Час, обставини знахідки та іiі подальша доля нам невідомі.

У 2017 р. в Коростенському районі був знайдений шилінг Пауля фон Русдорфа (1422-1441).

Час та обставини знахідки невідомі. Монета продана на аукціоні сайту «Віоліті» 16.12.2017 p.

Влітку 2012 р., за інформацією одного 3 Житомирських краєзнавців, в Любарському районі, поблизу с. Іванківці, в напрямку с. Демківці був знайдений шилінг Конрада фон Ерліхсхаузена (Елльріхсхаузена) (1441 - 1449).

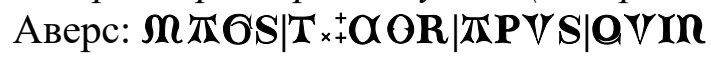

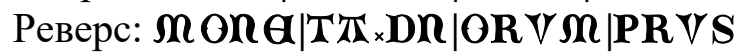

(m 1,48 г., Ø 21 мм.).

Даний тип монети описаний Ф.-А. Фоссбергом під № $858^{2}$. Монета знаходиться в приватній колекції.

У 2016 р. на теренах Любарського району було знайдено пореформений шилінг Міхаеля Кюхмейстера фон Штернберга (1414-1422). Монета має сліди подвійного удару штемпелем аверсу монети, а також недокарбування легенд аверсу i реверсу, що скоріш за все обумовлено дефектом монетної заготовки.

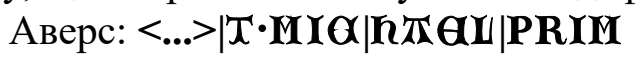

Реверс: $\mathbf{M} \mathbf{O}<$....... $>\mathbf{R}|\mathbf{O R} \mathbf{V} \mathbf{M}| \mathbf{P}<$...>

(m 1,30 г., Ø 21 мм.).

Монета опублікована її власником на аукціоні Інтернет-форуму «Віоліті», під час іiі продажу у квітні 2016 р. Даний тип монетної легенди реверсу, зокрема наявність прописної літери « $\mathbf{\Omega} »$, не описаний Ф.-А. Фоссбергом.

У квітні 2007 р. в Малинському районі, за свідченням Вадима Сироти, було знайдено грошовий скарб, до складу якого входило 433 монети кінця XV ст. першої половини XVIст., переважно напівгроші Яна Ольбрахта, Олександра Ягелончика, Сигізмунда I Старого та Сигізмунда II Августа. Самою молодою монетою в даному комплексі був напівгріш 1557 р. Серед монет скарбу була й 1 монета держави Тевтонського ордену в Пруссії - гріш 1521 р. великого магістра Альбрехта фон Бранденбург-Ансбаха (1510 - 1325). Обставини знахідки та подальша доля монет, які входили до скарбу нам невідомі.

У 1988 р. в Овруцькому районі, за інформацією Вадима Сироти, був випадково знайдений шилінг Пауля фон Русдорфа (1422 - 1441). Інформація про обставини знахідки та ії подальшу долю нам невідома.

У вересні 2011 р. в Ружинськму районі (за твердженням власника) був знайдений затертий дореформений шилінг Міхаеля Кюхмейстера фон Штернберга (1414 - 1422). На полі монети збереглися лише залишки гербового щита великого магістра, у тому числі й затертий геральдичний щит із орлом, легенда аверсу практично повністю втрачена.

Аверс: $<\ldots .>\mathbf{T}<\ldots \ldots .>\mathbf{G} \mathbf{L}^{\times} \mathbf{P R}<\ldots>$

\footnotetext{
${ }^{1}$ Орлик В. Знахідки на Волині... - C.46-47.

${ }^{2}$ Voßberg F. A. Op. cit. - S.168.
} 
Реверс: $<\ldots . .>$ T $\pi<\ldots . .>$ ORV $\boldsymbol{M}{ }^{\times} \mathbf{P R}<\ldots . .>$.

Даний шилінг опублікований власником на українському сайті «Віоліті» 3 проханням визначити та оцінити монету. Подальша доля цієї монети нам невідома.

Шилінг Іоганна фон Тіфена (1489 - 1497), за свідченням його власника був знайдений у першій половині 2012 р. на теренах Андрушівського району.

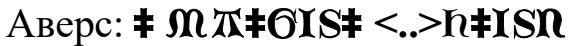

Реверс: $\uparrow<.>$ ONDTTMDNORVM <...>.

Обставини знахідки та її подальша доля нам невідомі.

У 2009 р. в смт. Миропіль Романівського району, за свідченням київського колекціонера Вадима Сироти, було знайдено шилінг Міхаеля Кюхмейстера фон Штернберга (1414 - 1422). Монета знаходиться в приватній колекції.

На теренах Житомирської області було знайдено пореформений шилінг Міхаеля Кюхмейстера фон Штернберга (1414 - 1422), монетний двір м. Торунь, емісія 1416 - 1422 рр.

Аверс: $\mathbf{M}<\ldots>T^{\circ} \mathbf{M I}<\ldots>$ T $O \mathbf{I I} \mid \mathbf{P R I M}$

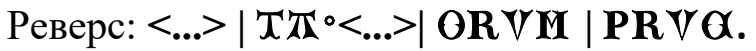

Монета опублікована її власником на українському сайті «Віоліті» 16 червня 2012 р. 3 проханням визначити час карбування та оцінити іiі вартість. Обставини знахідки та подальша її доля нам невідомі.

На теренах Житомирської області в 1998 р., за інформацією Вадима Сироти, був випадково знайдений шилінг Пауля фон Русдорфа (1422 - 1441). Обставини знахідки та подальша іiі доля нам невідомі.

На теренах Житомирської області в 2017 р. знайдено шилінг Мартіна Трухзеса фон Ветихаузена (1477 - 1489).

\section{Івано-Франківська область}

Наприкінці 2011 р. в Коломийському районі було знайдено грош Іоганна фон Тіфена (1489-1497).

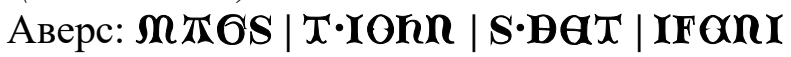

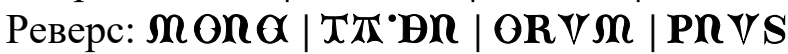

(m 1,11 г., Ø 20 мм.).

Монета опублікована іï власником на українському сайті «Віоліті» 3 проханням визначити емітента та оцінити ії вартість.

\section{Місто Київ}

Весною 1994 р. під час грунтових робіт у районі подільського пивзаводу, екскаваторником, за свідченням київського історика й колекціонера Вадима Сироти, був виявлений скарб, який зберігався у невеликому горщику. Наймолодшими монетами в даному комплексі були левендальдер (leeuvendaalder) провінції Кампеш (Нідерланди) та драйпелькер м.д. м. Рига 1649 року. Серед монет, які входили до цього скарбу, було дві монети великих магістрів держави Тевтонського ордену в Пруссії, зокрема шилінг Міхаеля Кюхмейстера фон Штернберга (1414 - 1422) та гріш 1525 р. останнього правителя цієї держави Альбрехта фон Бранденбург-Ансбах $(1510$ - 1325). Подальша доля монет із даного скарбу нам невідома. Інформація про скарб опублікована нами ${ }^{1}$.

У монографії відомого українського археолога, члена-кореспондента НАН України Г. Ю. Івакіна, присвяченій історичному розвитку м. Києва згадується про знахідку шилінгів великих магістрів Людвіга фон Ерліхсхаузена (Елльріхсхаузена)

${ }^{1}$ Орлик В. Монеты государства Тевтонского ордена в Пруссии... - С.39-45. 
Український нумізматичний щорічник. Вип. 1.

(1450 - 1467) та Мартіна Трухзеса фон Ветихаузена (1477 -1489) на Подолі, на місці Успенської церкви ${ }^{1}$.

На початку 2014 р. в м. Києві, в районі урочища Гончарі-Кожум'яки, була знайдена гріш-кліпа (рис.8) останнього Великого магістра держави Тевтонського ордену в Пруссії Альбрехт фон Бранденбург-Ансбах (1510 - 1325). Даний тип монети відповідає монеті із зібрання Державного музею у Варшаві, опублікованій Д. Міллє $\epsilon^{2}$.

\section{Київська область}

Весною 2012 р. поблизу р. Кам’янки Білоцерківського району, за свідченням власника, було знайдено шилінг Конрада фон Ерліхсхаузена (Елльріхсхаузена) $(1441-1449)$.

Аверс: $\mathbf{M}$ TIGS | $T: \alpha O R \mid$ THVS | OVIRT

Реверс: $\boldsymbol{M}$ On $\boldsymbol{\alpha} \mid \boldsymbol{T}<$.>PR | ORVM | PR VSI.

Монета опублікована їі власником на українському сайті «Віоліті» 3 червня 2012 р. 3 проханням визначити емітента та оцінити іiі вартість. А також під час спроби іiі продажу на аукціоні сайту «Віоліті» 11.06.2012 р. Подальша доля цієї монети нам невідома.

У липні 2014 р. в Білоцерківському районі був знайдений шилінг емісії часів великого магістра Конрада фон Ерліхсхаузена (Елльріхсхаузена) (1441-1449).

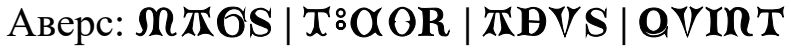

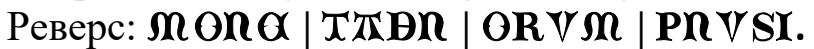

Монета опублікована її власником на українському сайті «Віоліті» 16 березня 2015 р. 3 проханням визначити емітента та оцінити її вартість.

Подальша доля цієї монети нам невідома.

У 2011 р. в районі впадіння р. Жереви в р. Тетерев, біля с. Тетерівське Іванківського району під час лісогосподарських робіт був знайдений монетний комплекс, до складу якого входила 51 монета другої половини XV - початку XVII, у тому числі й гріш Іоганна фон Тіфена (1489 - 1497).

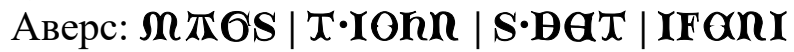

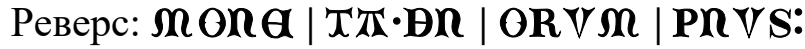

Даний скарб описаний і опублікований В. Безпальком та О. Лукашовим ${ }^{3}$.

У 2009 р. у с. Мотижин Макарівського району, за свідченням Вадима Сироти, був випадково знайдений шилінг Генріха Ройсса фон Плауена (адміністратора) (1467 - 1469). Подальша доля цієї монети нам невідома.

В Обухівському районі було знайдено шилінг Пауля фон Русдорфа (1422 1441).

Аверс: $\mathbf{M} \pi \mathbf{T} \mathbf{S}|\mathrm{T}: \mathbf{P} \pi| \mathbf{T} \mathbf{V}<\ldots \ldots \ldots \ldots .>$

Реверс: HO<...........>|OR $V \mathbf{M} \mid \mathbf{P R} \boldsymbol{Y} \boldsymbol{\alpha}$.

Час та обставини знахідки невідомі. Монета продана на аукціоні сайту «Віоліті» 22.02.2012 p.

У грудні 2012 р. в с. Сирники Рожищенського району, за повідомленням київського нумізмата Владислава Безпалька, був знайдений шилінг Пауля фон Русдорфа (1422-1441).

Аверс: MTOS $\mid \boldsymbol{T} \cdot \mathbf{P}$ 斥 $|\mathbf{V} \mathbf{U V S}| \mathbf{P}<\ldots>$

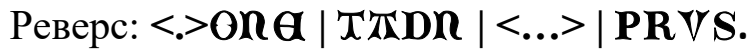

Подальша доля монети нам невідома.

\footnotetext{
${ }^{1}$ Івакін Г. Ю. Вказ. праця. - К., 1996. - С.142.

2 Miehle Danuta, Monety Zakonu Krzyzackiego/ Katalog monet ziem historycznie z Polska zwiazanych. Zbiory Muzeum Narodowego w Warszawie. -Warszawa, 1998. - S.192. - \#780.

${ }^{3}$ Безпалько В., Лукашов Д. Вказ. праця.
} 
У жовтні 2009 року на пагорбі на високому березі затоки в Рокитнянському районі любителями приладового металопошуку було виявлено більше двох десятків монет XV - XVI ст. (Свідниця, Литва, Польща, герцогство Прусське), серед яких, за твердженням власника, і шилінг Пауля фон Русдорфа (1422 - 1441).

Аверс: MTOS | T०P农 | VIVIS | PRIM

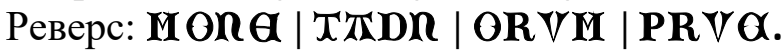

Монета продана на аукціоні сайту «Віоліті» 04.04.2010 p.

В с. Триліси Фастівського району був знайдений шилінг Генріха Реффле фон Ріхтенберга $(1470-1477)$.

Аверс: *MTGSTGR ${ }^{\circ} \mathbf{n} \mathbf{M}<\ldots>$

Реверс: $\mathfrak{h}<\ldots>\mathbb{T}^{\circ}$ DOMI.PR VS:

Подальша доля монети нам невідома.

\section{Львівська область}

У 2003 р., у Львівському районі, за свідченням київського історика Вадима Сироти, було знайдено шилінг Пауля фон Русдорфа (1422 - 1441). Час, обставини знахідки та іiї подальша доля нам невідомі.

У листопаді 2015 р. поблизу села Блищиводи Жовківського району був знайдений шилінг Іоганна фон Тіфена (1489 - 1497).

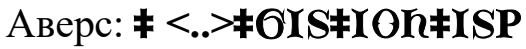

Реверс: ^м ONTT:DROR<...>PR.

Ця монета відповідає типу монет Держави Тевтонського ордену в Пруссії, описаним Ф.-А. Фоссбергом під № $1106^{1}$.

За свідченням власника цієї монети Максима Олійника, окрім даного шилінга, на тій місцевості в радіусі 100 м. ним було знайдено більше 130 польських денаріїв другої половини XIV - першої половини XV ст., 30 пулів львівського монетного двору (емісій Казимира III, Людовіка Угорського, Владислава Опольського) та фрагмент шилінга. Детальне ознайомлення з обрізком дозволило нам визначити його метрологічні характеристики та зробити певні висновки і припущення².

Основою для обрізку був дореформений шилінг Великого магістра Міхаеля Кюхмейстер фон Штернберга (1414 - 1422 рр.), карбований на монетному дворі в Торуні емісії $1414-1416$ рp.3.

Аверс: <...>hAbL<...>

Реверс: " $<$... > PRô

(m 0,27 г., $\varnothing 9,5 \times 11$ мм.).

Монета знаходиться у приватній колекції.

Другого лютого 2016 р. в лісових околицях м. Судова Вишня Мостиського району, за повідомленням місцевого любителя приладового металопошуку, було знайдено шилінг Мартіна Трухзеса фон Ветихаузена (1477 - 1489).

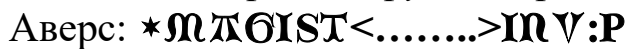

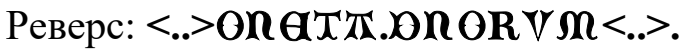

Час, обставини знахідки та ії подальша доля нам невідомі.

За 9 км. від м. Червоноград у південно-західному напрямку було знайдено шилінг Іоганна фон Тіфена (1489-1497).

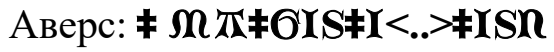

Реверс: $\bullet<. . . .>$ DN OR $\vee \boldsymbol{M}<$ <..>

(m 1,0 г., $\varnothing 19$ мм.).

Час знахідки та подальша доля монети нам невідома.

\footnotetext{
${ }^{1}$ Voßberg F. A. Op. cit. - S.189.

${ }^{2}$ Орлик В. Обрізаний шилінг... - C.54-56.

${ }^{3}$ Dutkowski J. Corpus Nummorum Civitatis Thorunensis / Jarosław Dutkowski, Adam Suchanek. - Gdańsk, 2010. - S.67-75.
} 
У вересні 2012 р. на межі між Сокальським районом Львівської області та Горохівським районом Волинської області був знайдений артіг (artig) Лівонського ордену. За класифікацією Г. Хальяка монета (рис.1) подібна до типу Т-1 №22를 , емісії $1375-1385 \mathrm{pp}$.

Аверс: $* \mathbf{M}<. . .>$ STRI $\times$ IIVYOIA

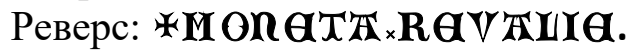

Отвір на монеті вказує, що вона використовувалася у якості прикраси. За свідченням власника артіга, котрий займається приладовим металопошуком, така знахідка є нетиповою для цієї місцевості, адже за його словами, там зустрічаються монети не старше емісій Сигізмунда III Вази. Монета була опублікована власником знахідки на сайті «Віоліті» для ії ідентифікації.

У 2014 р. в Сокальському районі була знайдена середньовічна підробка шилінгу держави Тевтонського ордену в Пруссії із «фантазійною» легендою.

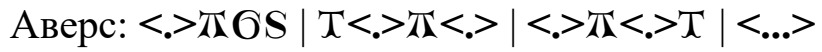

Реверс: $<. . .>|<\ldots>|$ Or $\mathbf{V} \mathbf{M} \mid<\ldots>$

(m 0,86 г., Ø 20,5 мм.).

Монета знаходиться у приватній колекції.

Восени 2015 р. в Сокальському районі був знайдений затертий і перегнутий шилінг Мартіна Трухзеса фон Ветихаузена (1477 - 1489).

Аверс: $<. . .>$ OIST $\boldsymbol{M} \pi \mathbf{\pi}<\ldots . . . . . . . . . .>$

Реверс: <...>ATT・DRORVM $<$...>

Час та обставини знахідки та ії подальша доля нам невідомі.

В околицях м. Сокаль був знайдений перегнутий шилінг Іоганна фон Тіфрена (1489 - 1497). Монета має значні механічні пошкодження зображення та легенди, особливо реверсу, а також тріщину на лінії перегину.

Аверс: $\neq \mathbf{M} \pi \mathbf{\pi}<$... $>$ IOh $¥ \mathbf{I S P}$

Реверс: <...>ATTRDRORV $\boldsymbol{M}<$...>.

Час та обставини знахідки нам невідомі. Дана монета була продана на аукціоні «Віоліті.

У листопаді 2016 р. у Прикарпатській частині Львівщини, зокрема в межах c. Великі Дідушичі Стрийського району, був знайдений скарб монет XV - XVI ст. Основну масу складають польські монети, у тому числі й монети Орденських міст, які перейшли під владу Польщі внаслідок Тринадцятирічної війни, 1 монета держави Тевтонського ордену в Пруссії, а також 7 монет герцогства Пруссії. 1497).

Щодо монети Тевтонського ордену, то це шилінг Іоганна фон Тіфена (1489 -

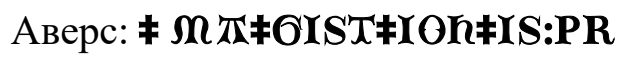

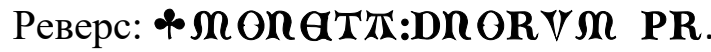

Дана монета була продана 16 грудня 2015 р. на аукціоні «Віоліті». Монета відповідає шилінгу, описаному Ф.-А. Фоссбергом під №1100².

\section{Одеська область}

У травні 2013 р. поблизу с. Старокозаче Білгород-Дністровського району було знайдено продірявлений шилінг великого магістра Генріх Реффле фон Ріхтенберга (1470 - 1477).

Аверс: * $\mathbf{m} \pi<$ <...>RIGVSG.

За свідченням власника монети, на місці, де вона була знайдена, йому траплялися монети Речі Посполитої та Османської імперії також з отворами. Це

\footnotetext{
${ }^{1}$ Haljak G. Livonian Coins. - P.78.

${ }^{2}$ Voßberg F. A. Op. cit. - S. 189.
} 
свідчить, що монета держави Тевтонського ордену в Пруссії, ймовірно, використовувалася у якості частини прикраси.

У 2012 р. у Саратському районі було знайдено обламаний і теж з отвором дореформений шилінг Міхаеля Кюхмейстера фон Штернберга (1414 - 1422).

Аверс: *<...>OST $\times \mathbf{M} \mathbf{I} \boldsymbol{\alpha}<\ldots . .>$

Реверс: * $\mathbf{m}<\ldots . . \ldots \ldots \ldots \ldots . . .>$

(m 0,94 г., Ø 19 мм.).

Характер отвору на монеті свідчить, що вона використовувалася у якості прикраси.

\section{Полтавська область}

У 2012 р. 24 квітня під час господарських робіт у лісі, за декілька кілометрів від с.м.т. Диканька, Диканьківського району був знайдений півскоєць (halbschoter) Bінріха фон Кніпроде (1352 - 1382) (Рис. 4).

Аверс: M ONETT:DOMMORRM 1 PRVSSIE

Реверс: *HONOR·MTGRI·I<..>ICIVM:DIUIO $<. .>$

(m 2,56 г., Ø 26 мм.).

Монета опублікована нами ${ }^{1}$.

У січні 2011 р. на українському сайті «Віоліті» 3 проханням визначити емітента та оцінити вартість був опублікований шилінг Генріха Реффле фон Ріхтенберга (1470 - 1477).

Аверс: *<.... InRIOVS:OVT

Реверс: $:$ :M On $\mathrm{G} T<\ldots \ldots . . . . .>V$

( $\varnothing 20$ мм.).

За свідченням власника, монета була знайдена у Пирятинському районі в складі грошового комплексу монет першої половини XVII ст. Подальша доля монети нам невідома.

В межах Полтавської області була знайдена одностороння срібна монета (брактеат) типу «Брама» емісії 1327 - 1338 рр. (Рис.1). Час та обставини знахідки нам невідомі. Монета була продана на аукціоні сайту «Віоліті» 08.12.2010 р. та знаходиться в приватній колекції.

У західній частині Полтавської області був знайдений шилінг Іоганна фон Тірена (1489-1497).

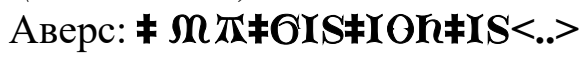

Реверс: 中 MONGTT DRORVMI

(m 1,1 г., Ø 20 мм.).

Подальша доля монети нам невідома.

\section{Рівненська область}

Весною 1993 р. під час господарських робіт на городі в с. Рясними Гощанського району, за свідченням київського історика Вадима Сироти, був знайдений шилінг Людвіга фон Ерліхсхаузена (Елльріхсхаузена) (1450 - 1467). Подальша доля монети нам невідома.

Весною 2011 р. на березі р. Горинь в с. Горбаків Гощанського району був знайдений шилінг Іоганна фон Тіфена (1489 - 1497).

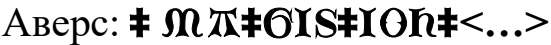

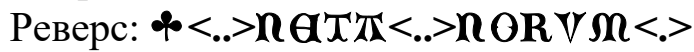

\footnotetext{
1 Orlyk W. Udział wojsk Zakonu Krzyżackiego w bitwie nad rzeką Worsklą w sierpniu 1399 r. w świetle źródeł numizmatycznych /Buletyn Numizmatyczny. - Nr 3, 2015. - S.175-180.; Idem. Teutonic Order and the Battle on the Vorksla River in August, 1399 (Numismatic Aspect). /Pieniadz a propaganda. Wspolne dziedzictwo Europy. - Augustow-Warszawa, 2015. - S.100-104.
} 
(m 0,76 г., Ø 18 мм.).

Подальша доля монети нам невідома.

Весною 2008 р. в Дубенському районі було знайдено пореформений шилінг Міхаеля Кюхмейстера фон Штернберга (1414 - 1422), монетний двір м. Торунь, емісія $1416-1422$ pp.

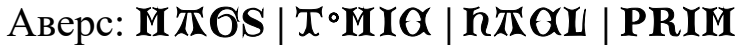 \\ Реверс: M ORA $\mid T^{\top} \boldsymbol{A}^{\circ} \mathbf{D R}$ | ORVM | PRV $\alpha$}

(m 1,46 г., Ø 22 мм.).

У 2013 р. 23 серпня між м. Дубно та с. Тараканів Дубенського району був знайдений шилінг Мартіна Трухзеса фон Ветихаузена (1477 - 1489).

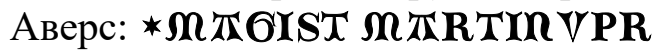

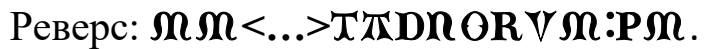

Власник шилінга виставив його фотографію для ідентифікації монети та оцінки їі вартості на Інтернет-форумі «Віоліті».

Поблизу с. Панталія Дубенського району, за інформацією одного 3 рівненських колекціонерів, було знайдено 2 монети номіналом півскойця (halbschoter) Biнріха фон Кніпроде (1352 - 1382). Власник монет надав нам неякісні фотографії однієї з цих монет, які все ж дозволяють ії ідентифікувати:

\section{Аверс: *M On<....>DOMInORVM $\uparrow$ PRVSSIE}

Реверс: *hOR OR ${ }^{\circ}$ MTRI

Час та обставини знахідки нам невідомі. Монета знаходиться в приватній колекції.

У березні 2015 р. на околицях м. Дубно було знайдено частину монетногрошового скарбу, розораного трактористом ще 1970-х роках під час посадки лісу. За відомостями дубенського краєзнавця Олександра Лісовського, у березні 2015 р. місцеві жителі випадково під час господарських робіт знайшли близько 1000 монет, переважно емісій Олександра Ягелончика, Сигізмунда I Старого та Сигізмунда II Августа, а також уламки горщика, в якому зберігався скарб. До складу скарбу входили монети XV - XVI ст., у тому числі й 20 монет держави Тевтонського ордену в Пруссії. Фотографію 4-х $з$ цих монет було виставлено на Інтернет-форумі «Віоліті» для їхньої ідентифікації оцінки вартості ${ }^{1}$.

Ознайомлення 3 іконографією та легендами на цих монетах дозволяє здійснити їхню ідентифікацію. Так, зокрема, тут представлені:

шилінг Пауля фон Русдорфа (1422 - 1441)

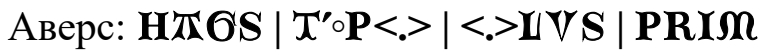

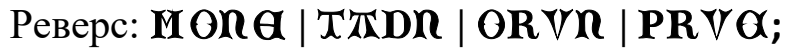

2 гроша Фрідріха фон Заксена (1498 - 1510)

Аверс: $\nabla$ HTOT | ST GR | FRID | IKVS

Реверс: HORA | TT2DR | ORVH | PRVS.

Аверс: $\nabla \mathbf{M}$ T $\mathbf{C I}|\mathbf{S T A R}| \mathbf{F}<.>\mathbf{I D}^{\prime} \mid \mathbf{I K} V \mathbf{S}$

Реверс: MORA | Tत्A.DR | ORVM | PRVS.

Подібні монети були описані Ф.-А. Фоссбергом під №№ 844, 1122, $1134^{2}$

Четвертою монетою 3 даного комплексу був середньовічний фальсифікат шилінга держави Тевтонського ордену в Пруссії. Аналіз іконографії та легенди монети дозволяють зробити припущення, що це фальсифікат пореформеного шилінга Міхаеля Кюхмейстера фон Штернберга (1414 - 1422).

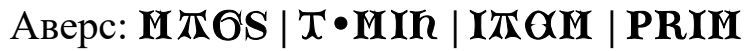

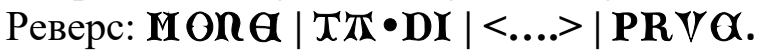

\footnotetext{
1 Violity. - Речь Посполитая (Литва, Польша) и связанные с ними [Електронний ресурс]. - Режим доступу: http://forum.violity.com/viewtopic.php?p=8796936\&highlight=\#8796936 /. - Назва з екрана. (28.09.2017)

${ }^{2}$ Voßberg F. A. Op. cit. - S.164, 194.
} 
Подальша доля монет нам невідома.

Окрім описаних вище 4-х монет із дубенського скарбу 2015 р., нам вдалося ідентифікувати ще ряд шилінгів держави Тевтонського ордену в Пруссії, які входили до складу цього монетно-грошового комплексу, зокрема 4 пореформені шилінги Міхаеля Кюхмейстера фон Штернберга (1414 - 1422), один із яких був проданий через аукціон «Віоліті» у квітні 2015 р.

На жаль, в архіві продавця збереглося лише фото аверса:

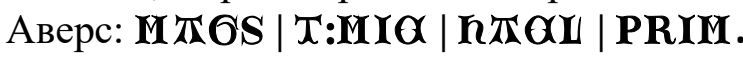

Зображення ще ряду монет держави Тевтонського ордену в Пруссії, які входили до даного монетного комплексу, було нам надано іншим місцевими мешканцями. Так, зокрема, пореформеного шилінга Міхаеля Кюхмейстера фон Штернберга (1414-1422).

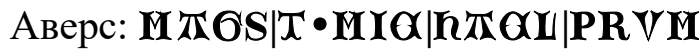

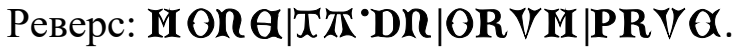

Монета відповідає шилінгу, описаному Ф.-А. Фоссбергом під №813 ${ }^{1}$

Шилінги Пауля фон Русдорфа (1422 - 1441).

Аверс: HA OS | T'”PA | VUVS | PRIM

Реверс: HOR $\mathbf{A}$ | TARDR | ORVM | PRV $\boldsymbol{\alpha}$.

Монета була продана на аукціоні «Віоліті» у лютому 2016 р., вона відповідає шилінгу, описаному Ф.-А. Фоссбергом під №837².

Аверс: HA GS | T’。PA | VIVYS | PRIM

Реверс: HOR $\mathbf{A}$ | TADR | ORVM | PRV $\boldsymbol{\alpha}$.

Монета була продана на аукціоні «Віоліті» у квітні 2016 р., вона відповідає шилінгу, описаному Ф.-А. Фоссбергом під №837³.

До цього ж комплексу належить й інший шилінг Пауля фон Русдорфа (1422 1441), виставлений для продажу на аукціоні «Віоліті» в липні 2015 р.

Аверс: HTOS | T:PT | VIVS | PRIH

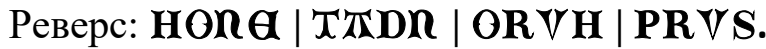

Монета відповідає шилінгу, описаному Ф.-А. Фоссбергом під №8424 .

Таким чином, монети держави Тевтонського ордену в Пруссії у дубенському скарбі 2015 р. складали близько 2\%. Вони були репрезентовані як оригінальні монети від Міхаеля Кюхмейстера фон Штернберга (1414 - 1422) до Фрідріха фон Заксена (1498 - 1510), так і середньовічні підробки, зокрема фальсифікатом пореформеного шилінга Міхаеля Кюхмейстера фон Штернберга $(1414-1422)^{5}$. За свідченням Олександра Лісовського, окрім даного монетного фальсифікату, у складі скарбу була значна кількість тогочасних монетних підробок польських монет.

У квітні 2010 р. в с. Миляч Дубровицького району, за інформацією Вадима Сироти, під час огородніх робіт було знайдено 2 монети - литовський напівгріш 1509 p. та шилінг великого магістра Тевтонського ордену Іоганна фон Тіфена $(1489-1497)$.

Поблизу с. Храпин Зарічненського району був знайдений шилінг Тевтонського ордену. Магістр, монетний двір та подальша доля монети нам невідомі.

У 1897 р. в селі Велика Мощаниця Дубенського повіту, Волинської губернії (на сьогодні с. Нова Мощаниця Здолбунівського району Рівненської області) був

\footnotetext{
${ }^{1}$ Ibid. - S.160.

${ }^{2}$ Ibid. - S.163.

${ }^{3}$ Ibid.

${ }^{4}$ Ibid.

${ }^{5}$ Orlyk W. Coins of the Teutonic Order contained in the hoard found in the suburbs of the city of Dubno of Rovenska region in march // Pruthenia, X, Olsztyn 2015, s.105-116
} 
знайдений скарб, до складу якого входив шилінг Пауля фон Русдорфа $(1422-1441)^{1}$. Монета зберігалася у мюнц-кабінеті Університету св. Володимира (м. Київ), подальша доля монети невідома.

Весною 2008 р. поблизу старовинного села Дермань (на сьогодні це два села, розташовані поруч - Дермань Перша і Дермань Друга) у Здолбунівському районі було знайдено шилінг Іоганна фон Тіфена (1489 - 1497).

Аверс: $\neq \mathbf{\Omega} \pi \neq \mathbf{T} \mathbf{I S} \neq \mathbf{I O h} \neq \mathbf{I S P}$

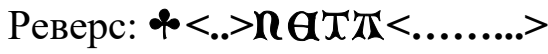

(m 1,02 г., Ø 20 мм.).

У серпні 2011 р. в околицях с. Бичаль Костопільського району, на високому березі р. Горинь, було знайдено шилінг Мартіна Трухзеса фон Ветихаузена (1477 1489).

Аверс: $* \boldsymbol{m} \pi \mathbf{T} \mathbf{O}<\ldots . . .>\operatorname{Trn}<\ldots>$

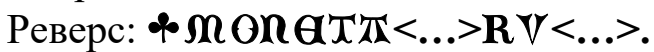

Подальша доля цієї монети нам невідома.

Восени 2016 р. на території Костопільського району був знайдений шилінг емісії часів великого магістра Пауля фон Русдорфа (1422 - 1441).

Аверс: $\boldsymbol{M}<\ldots . . .>\mathbf{P} \pi \mathbf{T}|\mathbf{V} \mathbf{U} \mathbf{V} \mathbf{S}| \mathbf{P R I}<.>$

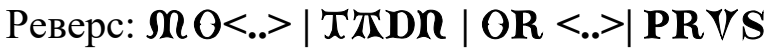

(m 1,22 г.).

Монета опублікована іï власником під час продажу на аукціоні Інтернетфоруму «Віоліті» ${ }^{2}$ у січні 2017 р. Фрагменти легенди на монеті, зокрема наявність на аверсі прописних літер « $\mathbf{\Omega}$ » у поєднанні із фрагментом легенди реверсу «PR VS», дають можливість віднести іï до шилінгів емісії 1426 - 1436 pp., карбованих на монетному дворі м. Гданська. Вона відповідає шилінгам, описаним Ф.А. Фоссбергом під №830-835³.

У 2001 р. в с. Гвіздків Корецького району, за свідченням київського історика i колекціонера Вадима Сироти, був знайдений шилінг Конрада фон Юнгінгена (1393 1407). Час, обставини знахідки та їі подальша доля нам невідомі.

Гріш Іоганна фон Тіфена (1489 - 1497), за свідченням його власника, котрий виставив фотографію монети для ідентифікації магістра на Інтернет-форумі «Віоліті», був знайдений 17 серпня 2012 р. в Млинівському районі, за 20 км. від районного центру, у полі. Гріш був злиплий із напівгрішем Сигізмунда II Августа $1560 \mathrm{p}$.

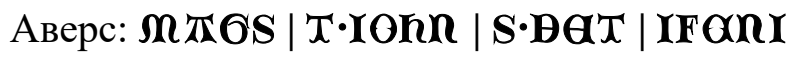

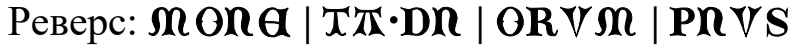

(m 1,51 г., Ø 21 мм.).

На аверсі монети є сліди подвійного удару штемпеля.

Власник, любитель приладового металопошуку, стверджує, що на місці знахідки вказаних монет були також знайдені й інші монети Сигізмунда I Старого та Сигізмунда II Августа, які мають належати до розораного ще в 60-х роках XX ст. скарбу. Ця монета була опублікована нами у статті, присвяченій монетам держави Тевтонського ордену в Пруссії у складі скарбів знайдених в Україні ${ }^{4}$. Монета зберігається у приватній колекції.

У січні 2017 р. на межі Млинівського району Ровенської та Луцького району Волинської областей був знайдений шилінг емісії великого магістра Пауля фон Русдорфа (1422 - 1441).

\footnotetext{
${ }_{1}^{1}$ Архів Національного музею України. - Ф.1. - Оп.1. - Спр.32. - Арк.2 зв.

${ }^{2}$ Violity. - Шиллинг тевтонский 1422-1440 [Електронний ресурс]. - Режим доступу: https://auction.violity.com/37439303shilling-tevtonskij-1422-1440. /. - Назва з екрана. (30.09.2017)

${ }^{3}$ Voßberg F. A. Op. cit. - S.163.

${ }^{4}$ Орлик В. Монеты государства Тевтонского ордена в Пруссии ... - С.39-45.
} 


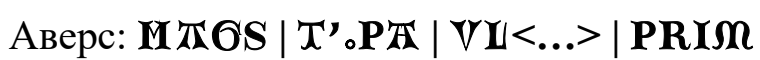

Реверс: HOR $\mathbf{A} \mid$ Tद्सD $|<\ldots>|$ PRV $\boldsymbol{\alpha}$

(m 1,05 г., Ø 20 мм.).

Монета опублікована iï власником, під час продажу на аукціоні Інтернетфоруму «Віоліті» ${ }^{1}$ у січні 2017 р. Вона відповідає шилінгу, описаному Ф. А. Фоссбергом під №8372

Весною 2008 р. за 20 км. від м. Рівне в напряку м. Луцька було знайдено фальсифікат пореформеного шилінга Міхаеля Кюхмейстера фон Штернберга (1414 - 1422).

\section{Аверс: MTAS | TंMIO |}

Реверс: $\mathbf{M O}<\ldots . . .>\mid$ ORVM $\mid \mathbf{P}<\ldots>$

(m 1,05 г., Ø 21 мм.).

Монета знаходиться в приватній колекції. Опублікована нами у статті, присвяченій проблемам фальшивомонетництва в державі Тевтонського ордену в Пруссії․

Влітку 1995 р. в м. Острозі на вул. Древлянській був знайдений монетноречовий скарб тривалого накопичення, який зберігався у глиняному глечику. Нумізматична частина скарбу складала 941 монету XIII - XVII ст., у тому числі й 2 монети держави Тевтонського ордену в Пруссії. Зокрема, шилінги великих магістрів Міхаеля Кюхмейстера фон Штернберга (1414 - 1422) та Пауля фон Русдорфа (1422 - 1441). Даний скарб досліджений, описаний та опублікований завідувачем відділу нумізматики «Державного історико-культурного заповідника м. Острога» О. Л. Позіховським та львівським нумізматом професором Р. М. Шустом

У квітні 2011 р., в с. Верхів Острозького району, за свідченням одного 3 рівненських краєзнавців, було знайдено монетний комплекс із 7 монет Держави Тевтонського ордену в Пруссії, зокрема, шилінг Мартіна Трухзеса фон Ветихаузена (1477 - 1489), 2 монети Іоганна фон Тіфена (1489 - 1497), 3 гроша Фрідріха фон Заксена (1498 - 1510) та одна не ідентифікована монета. Подальша доля цих монет нам невідома. У листопаді 2011 р. поблизу цього ж населеного пункту - с. Верхів Острозького району було знайдено шилінг Генріха Реффле фон Ріхтенберг (1470 1477) із літерою $\mathbf{\Omega}$ над щитом на реверсі монети.

Аверс: *<....>TAR

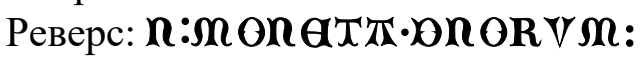

Монета опублікована іiі власником на українському сайті «Віоліті» 3 проханням визначити емітента та оцінити ії вартість.

Шилінг Пауля фон Русдорфа (1422 - 1441) знайдений поблизу с. Волосківці Острозького району восени 2012 р. Час, обставини знахідки та її подальша доля нам невідомі.

Пореформений шилінг Міхаеля Кюхмейстера фон Штернберга (1414-1422), за свідченням його власника, був знайдений 17 березня 2012 p. на пагорбі, розташованому на березі р. Горинь, поблизу селища Оженин Острозького району.

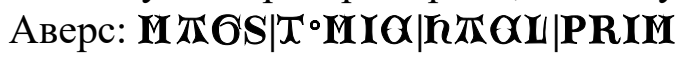

Реверс: M On $\mathbf{A} \mid \mathrm{T}$ TIDR|ORVM|PRIO.

Монета опублікована іï власником на українському сайті «Віоліті» 3 проханням визначити емітента та оцінити іiї вартість.

\footnotetext{
${ }^{1}$ Violity. - Шилінг тевтонський орден магістра Пауля фон Русодорфа (1422-1440 pp) [Електронний ресурс]. Режим доступу: https://auction.violity.com/36007957-shiling-tevtonskij-orden-magistra-paulya-fon-rusodorfa-1422-1440-rr. $\quad$ \% . Назва з екрана. (30.09.2017)

${ }^{2}$ Voßberg F. A. Op. cit. - S.163.

${ }^{3}$ Orlyk V. False Coins... - S.112-115

${ }^{4}$ Позіховський О. Л. Грошовий обіг на Волині XIV-XVII століття (За матеріалами монетних скарбів у фондах Державного історико-культурного заповідника міста Острог Рівненської області) / О. Л. Позіховський, Р. М. Шуст // Вісн. Львів. ун-ту. - Львів, 2005. - Вип. 39-40. - С. 529-547.
} 
У 2013 р. 20 травня поблизу м. Рівне було знайдено шилінг Іоганна фон Тіфена (1489-1497).

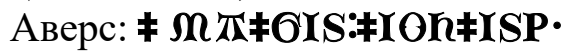

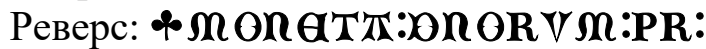

Поблизу смт. Степань Сарненського району був знайдений фрагмент пореформеного шилінга Міхаеля Кюхмейстера фон Штернберга (1414 - 1422). На аверсі даного фрагменту монети збереглася нижня частина гербового щита великого магістра, зокрема геральдичний щит із орлом та частина кругової легенди. На реверсі - гербовий щит Ордену з хрестом та частина кругової легенди.

Аверс: $<\ldots . . .>\left|\mathbf{T}^{\circ} \mathbf{M} \mathbf{I} \mathbf{X}\right|<\ldots \ldots .>$
Реверс: $<\ldots . . . . .>\mathbf{M} \mid \mathbf{O R}<\ldots \ldots .>$

Тернопільська область

У березні 2016 р. поблизу с. Вишгородок Лановецького району був знайдений шилінг, карбований в часи правління Пауля фон Русдорфа (1422 - 1441).

Аверс: MTAS | T०PT | VIVS | PRIM

Реверс: MORA | TTRDR | ORVM | PRV

(m 1,72 г., Ø 21 мм.).

Монета не відповідає жодному із шилінгів, описаних Ф.-А. Фоссбергом. А втім, в легенді монети містяться символи, характерні для монет, карбованих у м. Торуні в період $1422-1425$ pp. та 1426 - 1436 pp. Зокрема, використання літери «ТА без з'єднувальної лінії є характерним для емісій монет Пауля фон Русдорфа

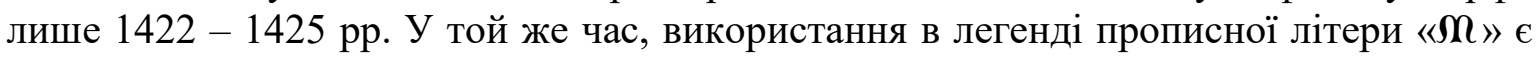
характерним для шилінгів, карбованих у 1426 - 1436 рр. Таким чином, можна стверджувати, що дана монета була карбована в м.д. м. Торуні не пізніше 1426 р.

Також у березні 2016 р. в околицях м. Ланівці був знайдений шилінг часів великого магістра Генріха Реффле фон Ріхтенберга (1470 - 1477).

Аверс: *MтTIST:hInRIars:O

Реверс: $\mathfrak{h} \cdot \mathbf{M}$ on $\boldsymbol{\theta} \pi \boldsymbol{T} \cdot \mathbf{D O M} \mathbf{M} \cdot \mathbf{P R V}$.

Монета відповідає типу, описаному Ф.-А. Фоссбергом під № $994^{1}$. Даний шилінг Генріха Реффле фон Ріхтенберга, а також описаний вище шилінг Пауля фон Русдорфа були опубліковані їхніми власниками на Інтернет-форумі «Віоліті» 3 проханням визначити емітента та оцінити їхню вартість ${ }^{2}$.

У середині 80-х років ХХ ст. в м. Теребовля, в районі садів, було знайдено скарб тривалого накопичення, до складу якого входило біля 4000 монет номіналом від подвійного денарія до талера. Наймолодшими з яких були монети Сигізмунда III Вази 1588 р. У складі скарбу було й декілька десятків монет держави Тевтонського ордену в Пруссії. Інформацію про даний скарб ми отримали з декількох джерел у Тернопільській та Львівській областях. Одним із теребовлянських нумізматів нам були надані фотографії пореформеного шилінга (рис.7) Міхаеля Кюхмейстера фон Штернберга (1414 - 1422) та гроша Іоганна фон Тіфена (1489 - 1497), які входили до складу згаданого монетного комплексу, а тепер зберігаються у приватній колекції в м. Теребовля.

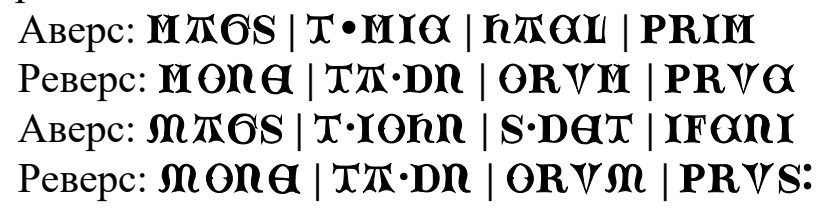

${ }^{1}$ Voßberg F. A. Op. cit. - S.183.

2 Violity. - Монета с крестом на определение и оценку [Електронний ресурс]. - Режим доступу: http://forum.violity.com/viewtopic.php?p=9955609\#9955609 /. - Назва з екрана. (28.09.2017) 
Інформація про скарб та фотографії монет Міхаеля Кюхмейстера фон Штернберга та Іоганна фон Тіфена опубліковані нами ${ }^{1}$.

На початку грудня 2012 р. поблизу с. Кам'янка Теребовлянського району був знайдений грошовий комплекс, до складу якого входило декілька празьких грошів та три монети держави Тевтонського ордену в Пруссії.

Зокрема, пореформений шилінг Міхаеля Кюхмейстера фон Штернберга $(1414-1422)$.

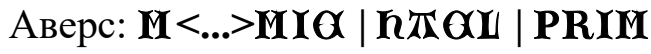

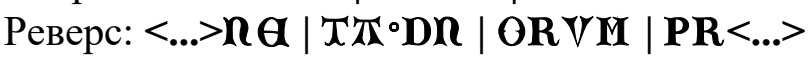

Шилінг Пауля фон Русдорфа (1422-1441).

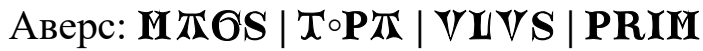

Реверс: MORA | TRDR | ORVM | PRVA.

Гріш Фрідріха фон Заксена (1498-1510).

Аверс: $\nabla \mathbf{M}$ T OI | STAR | FRID |IKVS

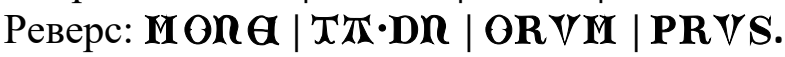

Дану знахідку можна віднести до категорії випадково загублених скарбів, зокрема загубленого гаманця.

Наприкінці жовтня 2014 р., в лісі поблизу м. Теребовля, був знайдений грошовий комплекс, до складу якого входило 50 монет, у тому числі й шилінг Іоганна фон Тіфена (1489-1497).

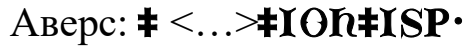

Реверс: $中 \mathbf{M}$ ON $\mathbf{A}<\ldots>$ V $\mathbf{M} \mathbf{P}$.

За свідченням власника комплексу, вони були продані ним через аукціон «Віоліті».

У липні 2016 поблизу с. Струсів Теребовлянського району був знайдений шилінг Мартіна Трухзес фон Ветихаузена (1477 - 1489).

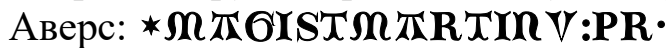

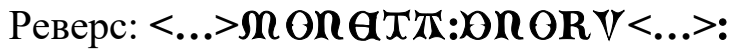

Обставини знахідки невідомі. Монета продана на аукціоні «Віоліті» 1 серпня 2016 р. за 170 грн.

У 2012 році, за свідченням хмельницького дослідника Р. Саввова, в околицях м. Тернополя був знайдений грошовий скарб, до складу якого входило 314 монет XIV - початку XV ст., в тому числі й шилінг Міхаеля Кюхмейстера фон Штернберга $(1414-1422)^{2}$.

У грудні 2011 р., за свідченням одного із тернопільських любителів приладового металопошуку, був знайдений шилінг Конрада Цолльнера фон Ротенштейна (1382 - 1390). Власник монети люб'язно надав нам відомості про знахідку, iї метрологічні характеристики та фотографію монети.

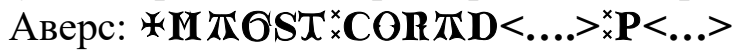

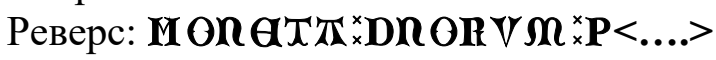

(m 1,69 г., Ø 18 мм.).

В межах Тернопільської області був знайдений затертий шилінг Іоганна фон Тіфена (1489 - 1497). Час і обставини знахідки нам невідомі.

\section{Хмельницька область}

На території Білогірського району в 2015 р. був знайдений шилінг Іоганна фон Тіфена (1489-1497)

Аверс: $¥<$...>\$OIST $¥ \mathbf{I O h < . . . > ~}$

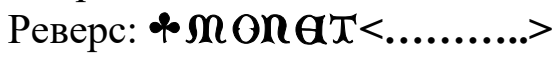

${ }_{1}^{1}$ Орлик В. Монеты государства... - С.39-45.

${ }^{2}$ Саввов Р. Указ. соч. - С. 16 
(m 0,65 г., Ø 18 мм.).

Тип монети відповідає типу, описаному Ф.-А. Фоссбергом під № 1090¹. Монета була продана на аукціоні сайту «Віоліті» 14 квітня 2016 р.

У 2003 р. в околицях с. Стара Пісочна був знайдений скарб, до складу якого входило 326 монет XIV - початку XV ст., у тому числі й 2 шилінги держави Тевтонського ордену ${ }^{2}$. Скарб описаний хмельницьким дослідником Р. Саввовим.

В березні 2011 р. поблизу с. Юринці Городоцького району було знайдено грошовий скарб, у складі якого був шилінг Пауля фон Русдорфа (1422 - 1441).

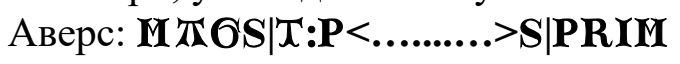

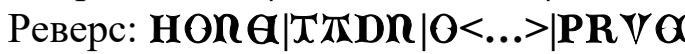

Монета опублікована нами ${ }^{3}$.

Літом 1889 р. в с. Татариски, Ушицького повіту Подільської губернії (тепер с. Ставище Дунаєвецького району) був знайдений скарб, до складу якого входило 1268 монет XIV - XVI ст., у тому числі й 7 монет магістрів Тевтонського ордену ${ }^{4}$. Опис цього скарбу здійснив Камянець-Подільський колекціонер Михайло Грейм, до якого власне й був доставлений вказаний грошовий комплекс. Інформація про даний скарб з посиланням на публікацію М. Грейма містилася й у «Археологічній карті Подільської губернії», складеної Свтимом Сіцінським і опублікованої в Працях одинадцятого археологічного з'їзду ${ }^{5}$. Примітно, що серед цього корпусу монет, окрім 7 монет, карбованих безпосередньо від імені магістрів Ордену, ще 60 монет були пов'язані із колишніми теренами орденської держави. Зокрема, було 8 монет, карбованих у м. Гданську в часи Казиміра Ягелончика та 17 гданських монет 30 70-х років XVI ст. Також було 4 монети часів Казиміра Ягелончика, карбованих у м. Торунь і 1 монета м. Ельблонг. Окрім названих 30 монет, карбованих у містах Тевтонського ордену, які перейшли під польську владу, до складу скарбу входило 31 монета прусська 1528 - 1559 рр. Таким чином, серед 1268 монет даного скарбу 63 монети $(5,3 \%)$ були прямо чи опосередковано пов'язані із містами Тевтонського ордену. Переважну частину скарбу складали монети, карбовані на теренах Великого князівства Литовського - 1042 шт. (83 \%), що свідчить про тісні економічні зв'язки Подільського воєводства Королівства Польського із землями ВКЛ у XV - XVI ст., а не із традиційними польськими торгівельними центрами Краковом, Познанню та Вроцлавом, які мали власні монетні двори й карбували польські монети. Враховуючи значну відстань від українського Поділля, де був тезаврований скарб до ганзейських міст, у яких в різні часи були монетні двори Тевтонського ордену й чиї монети входили до цього скарбу, ми черговий раз можемо стверджувати, що нумізматичні джерела вказують на тісні торговельні зв'язки купецтва міст Торуня, Гданська та Кенігсбергу з мешканцями українських середньовічних земель, у даному випадку - із товаровиробниками та торговцями із Західного Поділля.

Восени 2008 р. поблизу с. Берездів Славутського району був знайдений шилінг Іоганна фон Тіфена (1489-1497).

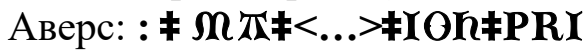

Реверс: $中 \boldsymbol{M O} \mathbf{O}<\ldots . . . . .>\mathbf{n O R}: \mathbf{P}$.

Монету опублікував її власник для визначення на сайті «Віоліті».

Поблизу м. Камянець-Подільський знайдено шилінг Мартіна Трухзес фон Ветихаузена (1477 - 1489).

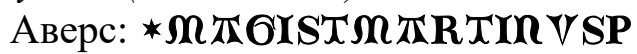

\footnotetext{
${ }^{1}$ Voßberg F. A. Op. cit. - S.189.

${ }^{2}$ Саввов Р. Указ. соч. - С.16.

${ }^{3}$ Орлик В. Монеты государства... - C.39-45.

${ }^{4}$ Greim M. Wykopaliska monet w gubernii Podolskiej // Wiadomości Numizmatyczno-Archeologicznych. - 1891. - \#2. S.207;

${ }^{5}$ Сецинский Е. Указ. соч. - С.291
} 


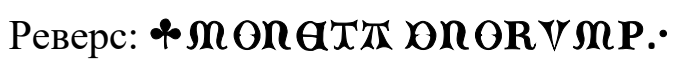
колекції.

Час та обставини знахідки нам не відомі. Монета знаходиться в приватній

Восени 2016 р. поблизу с. Старий Кривин, Славутського району (приблизно на середині дороги Славута-Острог) був виявлений середньовічний фальсифікат шеляга Тевтонського ордену. колекції.

Час та обставини знахідки нам не відомі. Монета знаходиться в приватній

У 2016 р. на території Камянець-Подільського району був знайдений шилінг Конрада фон Юнгінгена (1393 - 1407). Монета (рис.5) має механічні пошкодження, вона містить сліди вирівнювання та отвір.

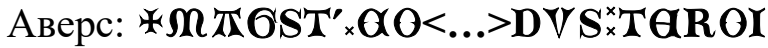

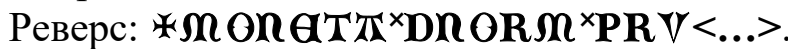

Час та обставини знахідки нам невідомі. Монета знаходиться у приватній колекції.

У грудні 2011 р. на сайті «Віоліті» для iï ідентифікації був опублікований продірявлений шилінг Іоганна фон Тіфена (1489 - 1497).

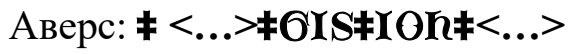

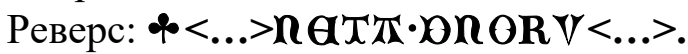

За свідченням власника, монета була знайдена поблизу с. Клопотівці Деражнянського району. Механічне пошкодження монети відповідає характерному для середньовічних монет способу виявлення монетних фальсифікатів шляхом їхнього продірявлення. Подальша доля цієї монети нам невідома.

Влітку 2003 р. під час археологічних досліджень пізньосередньовічної пам'ятки поблизу смт. Меджибіж Летичівського району було виявлено шилінг великого магістра Конрада фон Ерліхсхаузена (Елльріхсхаузена) $(1441-1449)^{l}$.

У червні 2012 р. на сайті «Віоліті» для ii ідентифікації був опублікований затертий шилінг Іоганна фон Тіфена (1489-1497).

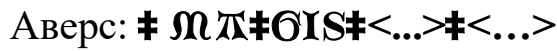

Реверс: $\leftrightarrow<\ldots>$ T $\pi \cdot 0 \cap 0<\ldots . . .>$

( 18 мм.).

За свідченням власника, монета була знайдена у червні 2012 р. неподалік від смт. Меджибіж Летичівського району.

Першого липня 2015 р., поблизу м. Летичів був знайдений шилінг адміністратора держави Тевтонського ордену в Пруссії Генріха Ройсс фон Плауена (1467-1469).

Аверс: <...>nRIaVSoUOGVTGR<...>

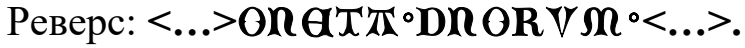

У грудні 2011 р. на сайті «Віоліті» для iï ідентифікації був опублікований продірявлений шилінг Мартіна Трухзеса фон Ветихаузена (1477-1489).

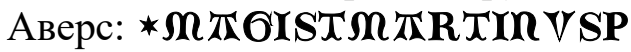

Реверс: ^⿻ оп

(m 1,1 г., $\varnothing 18$ мм.).

За свідченням власника, монета була знайдена на території Новоушицького району. Час, обставини знахідки та подальша доля цієї монети нам невідомі.

Також на території Новоушицького району, за свідченням місцевого любителя приладового металопошуку, ним був знайдений монетний комплекс «гаманець», до складу якого входив шилінг Мартіна Трухзеса фон Ветихаузена

${ }^{1}$ Демидко С.Ю., Погорілець О.Г., Стопенчук С.М. Вказ. праця. - С.9. 
(1477 - 1489). Час, обставини знахідки, склад комплексу та подальша доля цих монет нам невідомі.

Восени 2012 р. на території Старокостянтинівського району був знайдений пореформений шилінг Міхаеля Кюхмейстера фон Штернберга (1414 - 1422).

Аверс: <...>OS $|\pi \cdot \mathbf{M} \mathbf{I} \boldsymbol{\alpha}|<\ldots>\mathbf{O} \mathbf{I} \mid \mathbf{P R}<\ldots . .>$

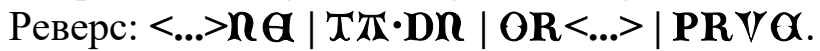

Монета була опублікована для ідентифікації на сайті «Віоліті» іії власником у січні 2013 p.

Тієї ж осені на теренах Старокостянтинівського району було знайдено надламаний гріш Іоганна фон Тіфена (1489 - 1497).

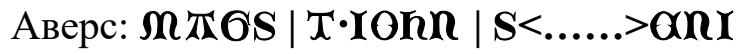

Реверс: <..... $>\boldsymbol{\pi} \bullet \mathbf{D R}|\mathbf{O R} \boldsymbol{V} \mathbf{M}| \mathbf{P R V S} \bullet$

Час, обставини знахідки та ії подальша доля нам невідомі.

На території Старокостянтинівського району також було знайдено шилінг Пауля фон Русдорфа (1422 - 1441).

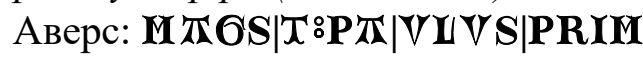

Реверс: <..... >DR|OR VM|PRVS.

Монета опублікована іiі власником на аукціоні Інтернет-форуму «Віоліті» у квітні 2016 р. Шилінг відповідає типу монет, описаних Ф.-А. Фоссбергом під №8281, карбованих на м.д. м. Торунь в 1422 - 1425 рр. Час, обставини знахідки та ії подальша доля нам невідомі.

У 2014 р. 9 вересня на Інтернет-ресурсі «Віоліті» було виставлено для ідентифікації грошовий комплекс із 12 монет XV - XVI ст., до складу якого входив i обламок шилінга адміністратора держави Тевтонського ордена в Пруссії Генріха Ройсса фон Плауена (1467 - 1469 рр.).

$$
\begin{aligned}
& \text { Аверс: *hIn }<\ldots . .>\text { L OOVTn GS }<\ldots>
\end{aligned}
$$

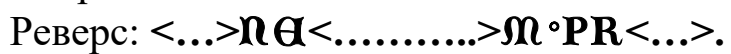

За залишками легенди аверсу, зокрема надписом «LOOVTnGS», дана монета відповідає типу монет, описаних Ф.-А. Фоссбергом під №907. За свідченням власника даних монет, вони були ним знайдені 7 вересня 2014 р. в ліску на околиці смт. Чемерівці, Чемеровецького району Хмельницької області.

За межами смт. Чорний острів Хмельницького району, в напрямку селища Наркевичі, в 2012 р. було знайдено сильно зношені 2 монети держави Тевтонського ордену в Пруссії, зокрема дореформений шилінг Міхаеля Кюхмейстера фон Штернберга (1414-1422).

Аверс: $<. . .>\mathbf{S}<$. $>\mathbf{M} \mathbf{I} \boldsymbol{\alpha} \mathbf{n}<\ldots . . . . . . . .>>$

Реверс:* $\mathbf{M}$ On $\mathbf{G} T<$... $>\mathbf{D}<\ldots . . . . .>\mathbf{P R V}$

та шилінг Іоганна фон Тіфена (1489 - 1497)

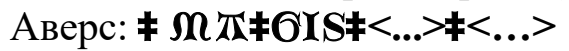

Реверс: $\uparrow м$ on $\boldsymbol{\theta}<\ldots . . . . . . . . .>$.

Час, обставини та подальша доля знахідки автору невідомі.

У жовтні 2015 р. на території Хмельницького району, за свідченням місцевого любителя приладового металопошуку, був знайдений шилінг магістра Мартіна Трухзеса фон Ветихаузена (1477 - 1489). Монета була опублікована для ідентифікації на сайті «Віоліті» її власником.

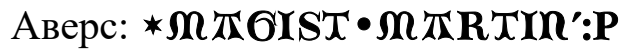

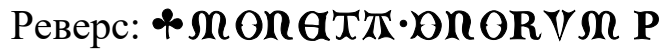

(m 0,95 г.).

Тип монети відповідає типу, описаному Ф.-А. Фоссбергом під № $1059^{2}$

\footnotetext{
${ }^{1}$ Voßberg F. A. Op. cit. - S.163.

${ }^{2}$ Ibid. - S.187.
} 
Подальша доля монети нам невідома.

У 2013 р. на околицях смт. Теофіполь був знайдений грошовий скарб, до складу якого входило близько 2000 монет, основну масу скарбу складали краківські півгроші 1492 - 1516 рр., окрім цього, у скарбі були монети ВКЛ, Пруссії та ін. Наймолодша монета даного комплексу - литовський подвійний денарій 1570 p., а найстарші - півгроші Владислава Ягайла (1386 - 1434). Єдина монета держави Тевтонського ордену в Пруссії у складі даного скарбу - шилінг Конрада фон Ерліхсхаузена (Елльріхсхаузена) (1441 - 1449 рр.) м.д. м. Торунь. Це єдина монета держави Тевтонського ордену в Пруссії у складі даного скарбу.

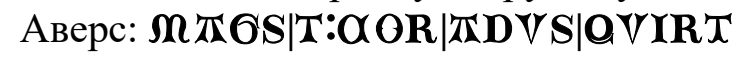

Реверс: $\mathbf{m}$ On $\mathbf{A} \mid \mathrm{T}$ T:DR|ORVM:|PRVSI

(m 1,59 г., Ø 21 мм.).

Даний тип монети із повністю наведеною легендою опубліковано нами вперше ${ }^{1}$. Подібні були описані Ф.-А. Фоссбергом під № $871^{2}$ та сучасними польськими дослідникам Ярославом Дутковські та Адамом Сушанеком³. Проте монета із Теофіпольського скарбу має певні відмінності в легенді, зокрема наявністю на реверсі символу : після фрагменту легенди «OR $\mathbf{V} \mathbf{M} »$.

Аналогічна монета до публікованої нами міститься у каталозі монет Тевтонського ордену із зібрання Національного музею у Варшаві під №558, проте в ній відсутні деякі фрагменти в легендах аверсу та реверсу ${ }^{4}$. Описана нами монета має ступінь рідкості R6 і зберігається в приватній колекції, з якою ми мали можливість ознайомитися.

У 1993 р. на території Шепетівського району, за свідченням київського колекціонера Вадима Сироти, був випадково знайдений шилінг Мiхаеля Кюхмейстера фон Штернберга (1414 - 1422). Тип монети (дореформений/пореформений) та подальша доля монети нам невідомі.

На початку квітня 2016 р. на околицях с. Пашуки Шепетівського району був знайдений шилінг Пауля фон Русдорфа (1422 - 1441).

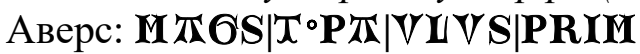

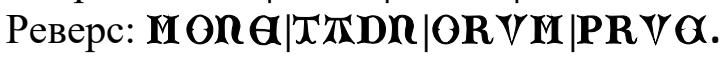

Монета опублікована іiі власником під час продажу на аукціоні Інтернетфоруму «Віоліті» у квітні 2016 р. Шилінг відповідає типу монет, описаних Ф. А. Фоссбергом під №826 $6^{5}$, карбованих на м.д. м. Торунь в $1422-1425$ рр.

На території Хмельницької області було знайдено ще ряд монет держави Тевтонського ордену в Пруссії, проте, на жаль, ми не маємо більш детальної інформації про локалізацію цих знахідок.

За свідченням одного із хмельницьких краєзнавців, в межах області був знайдений шилінг Biнpixa фон Кніпроде (1352 - 1382) (Рис. 3). Час і обставини знахідки нам невідомі.

У квітні 2015 р. на українському Інтернет-ресурсі «Віоліті» було виставлено для ідентифікації 5 монет XVII ст. (гроші та солід польського короля Сигізмунда III) та шилінг Іоганна фон Тіфена (1489 - 1497). За словами власника монет, вони були знайдені в радіусі 1 метра поблизу русла річки Хомора в Хмельницькій області.

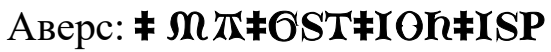

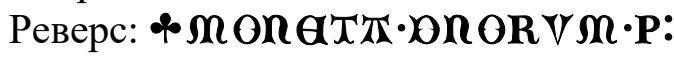

\footnotetext{
${ }^{1}$ Orłyk W. Rzadki wariant... - S.258-263.

${ }^{2}$ Voßberg F. A. Op. cit. - S.168.

${ }^{3}$ Dutkowski J. Op. cit. - S.87. - \# 866

${ }^{4}$ Miehle D. Monety Zakonu Krzyzackiego/ Katalog monet ziem historycznie z Polska zwiazanych. Zbiory Muzeum Narodowego w Warszawie. - Warszawa 1998. - S.138. - \#558.

${ }^{5}$ Voßberg F. A. Op. cit. - S.163.
} 
Дана монета відповідає типу монет, описаних Ф.-А. Фоссбергом під №1089. Час, обставини та подальша доля знахідки нам невідомі.

Шилінг Пауля фон Русдорфа (1422 - 1441).

Аверс: HA OS | T'”PA | VUVS | PRIM

Реверс: HORA | TARDR | ORVM | PR $\mathbf{X} \boldsymbol{\alpha}$.

Монета опублікована їі власником під час продажу на аукціоні Інтернетфоруму «Віоліті» у березні 2016 р. Монета, за свідченням продавця, була знайдена у вересні 2015 р. Вона, відповідає шилінгу, описаному Ф. А. Фоссбергом під №837².

Шилінг Пауля фон Русдорфа (1422 - 1441).

Аверс: <...> $\mid T^{\prime}{ }_{0}$ PA $\mid$ VIVVS | PRIM

Реверс: HOR $\mathbf{A}$ | TARDR | ORVM | <...>. |

Монета опублікована іiі власником під час продажу на аукціоні Інтернетфоруму «Віоліті» у серпні 2016 р. Час, місце та обставини знахідки невідомі. Монета відповідає шилінгу, описаному Ф.-А. Фоссбергом під №837².

\section{Черкаська область}

Восени 2012 р. поблизу м. Городище, біля струмка в лісі, було знайдено шилінг Лівонського ордену та шилінг Мартіна Трухзеса фон Ветихаузена (1477 1489). Перша монета була опублікована для ідентифікації на сайті «Віоліті» iï власником, а про другу - повідомлено автору із наданням фотографії.

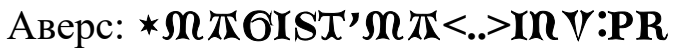

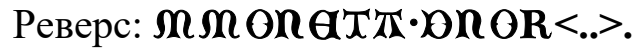

Подальша доля монети нам невідома.

У травні 2006 р. в с. Піщане Золотоніського району був знайдений шилінг держави Тевтонського ордену в Пруссії․ Через незадовільний стан збереження монети не визначено ім'я великого магістра.

На території Уманського району був знайдений шилінг Іоганна фон Тіфена $(1489-1497)$.

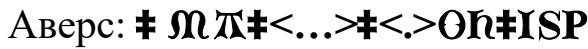

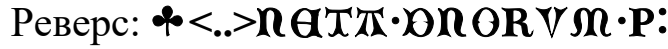

Час, обставини та подальша доля знахідки автору невідомі.

Весною 2014 р. поблизу с. Худяки Черкаського району на відмілинах Кременчуцького водосховища було знайдено артінг Лівонського ордену XIV початку XV ст.

\section{Аверс: <..>OISTRI× UIVORIA

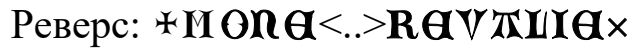 \\ (m 0,84 г., Ø 19 мм.).}

За свідченням власника артіга, котрий займається приладовим металопошуком, монета була знайдена разом із монетами Золотої орди, київським наслідуванням Джалал уд-Діна Махмуд Джанібека та празькими грошами. Монета була опублікована власником знахідки на сайті «Віоліті» для іiі ідентифікації. За класифікацією Г. Хальяка, монета подібна до типу Т-1 №№21-224, емісії 1375 1385 рр. Проте наявний символ «х» в легенді реверсу (рис.9 ) цієї монети немає аналогів у зазначеному каталозі.

У вересні 2015 р. в лісі на західній околиці с. Кумейки Черкаського району місцевим мешканцем був випадково виявлений монетний комплекс - «гаманець», до складу якого входили декілька десятків монет XV - XVII, зокрема, польських,

\footnotetext{
${ }^{1}$ Ibid.

${ }^{2} \mathrm{~S}$.

${ }^{3}$ Шестопал А. В. Вказ. праця. - С.52.

${ }^{4}$ Haljak G. Op. cit. - P.78.
} 
угорських, німецьких, а також шилінг часів великого магістра Тевтонського ордену Генріха Реффле фон Ріхтенберга (1470 - 1477).

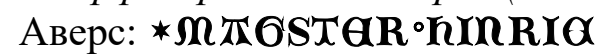

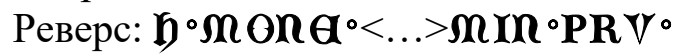

(m 0,71 г., Ø 20,5 мм.).

Дана монета була продана на аукціоні «Віоліті» в лютому 2016 р.

У 1865 року, мешканці м. Чигирин Петро і Михайло Рясики та Ганна Назаренко викопали глечик із 1530 срібними монетами. Скарб був переданий до Мінц-кабінету університету св. Володимира, де він був детально описаний К. Страшкевичем ${ }^{1}$. Серед монетного комплексу була й одна невизначена монета, яка за іконографією відповідала шилінгам держави Тевтонського ордену в Пруссії, карбованим в період 1382 - 1416 pр., М. Біляшівський повторює майже дослівно опис, зроблений К. Страшкевичем: «Грош - (затертый). Л. (аверс - B.О.) Сердцеобразный гербовый щит с большим крестом занимающим всю поверхность щита; посредине меньший щит; кругом готические затертые буквы. О (реверс B.O.). Такой же четырехпольный щит, кругом подобные буквы. -8 л. - 20 дол. $1 .{ }^{2}$. Як бачимо, в даному описі присутні й метрологічні дані монети, зокрема іiі діаметр - 8 ліній, що відповідає 20,32 мм. та вага - 20 долей, що відповідає 0,89 г. Беручи до уваги значну затертість монети, що має супроводжуватися і певною втратою її початкової ваги, а також враховуючи розмір та іконографічні особливості, ми схиляємося до думки, що у складі Чигиринського скарбу був дореформений шилінг Міхаеля Кюхмейстера фон Штернберга. Адже лише для шилінгів Тевтонського ордену, карбованими в період 1382 - 1416 pp., характерним $\epsilon$ згадуваний вище «гербовый щит с большим крестом занимающим всю поверхность щита; посредине меньший щит», а значні відхилення від монетно-вагової норми були характерними для дореформених емісій Міхаеля Кюхмейстера фон Штернберга. Цікаво, що К. Страшкевич припускав, що аналізована монета належала до емісій держави Тевтонського ордену, й у даному описі згадує ще одну подібну монету, яка зберігалася у ввіреному йому мінц-кабінеті університету, вказуючи, що «Кажется, это монета великих тевтонских магистров 14-го или 15-го века: тип, величина и вес сходны с одною находящеюся в нашей новой коллекции (№1957), которая также еще до сих пор ближе не определена» ${ }^{3}$.

\section{Чернівецька область}

У 2010 році в околицях с. Грубна Сокирянського району був знайдений скарб, що включав 1351 монету XIV - початку XV ст., у тому числі й 1 шилінг держави Тевтонського ордену ${ }^{4}$. Скарб описаний хмельницьким нумізматом Р. Саввовим.

Шилінг Мартіна Трухзеса фон Ветихаузена (1477 - 1489). Монета опублікована 10 серпня 2012 р. ii власником на сайті «Віоліті» для ідентифікації. За словами власника, шилінг був знайдений ним у серпні 2012 р. на території Сторожинецького району.

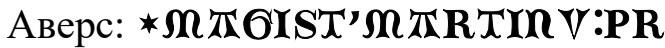

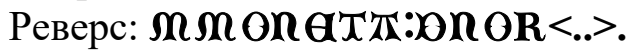

Подальша доля монети нам невідома.

\section{Чернігівська область}

Восени 2014 р. на території Бобровицького району був знайдений монетногрошовий комплекс переважно литовських і польських монет, монети герцогства

\footnotetext{
${ }^{1}$ Страшкевич К. Указ. соч. - №12. - С.9-39

${ }^{2}$ Беляшевский Н. Монетне клады Киевской Губернии. - Киев: Тип. Т.Г. Корчак-Новитского, 1889. - С.140.

${ }^{3}$ Страшкевич К. Указ. соч. - С.39.

${ }^{4}$ Саввов Р. Указ. соч. - С. 18.
} 
Прусського, маркграфства Бранденбургу-Кюстрина, Герцогство Пфальц-Зиммерн, міст Брауншвейг та Геттінген Нижньої Саксонії, графства Равенсберг, абатства Херфорд, Угорського королівства, Богемії. До складу цього комплексу входили також 2 монети держави Тевтонського ордену в Пруссії, зокрема дореформений шилінг Міхаеля Кюхмейстера фон Штернберга (1414 - 1422) та шилінг Пауля фон Русдорфа (1422 - 1441). Переважна частина цих монет була продана через аукціон «Віоліті».

У березні 2014 р. у Ніжинському районі був знайдений монетний комплекс (гаманець), до складу якого входило вісім монет. Зокрема, коронний квартник (півгріш) Владислава Ягайла емісії 1431 - 1434 рр. м.д. м. Краків та сім дореформених шилінгів (рис.6) Великого магістра Міхаеля Кюхмайстера фон Штернберга.

Даний монетний комплекс описаний та опублікований нами ${ }^{1}$.

У 1990 р. 18 вересня, за інформацією київського колекціонера Вадима Сироти, під час господарських робіт на городі в смт. Любеч Ріпкінського району був знайдений шилінг Міхаеля Кюхмейстера фон Штернберга (1414 -1422). Подальша доля монети нам невідома.

\section{Знахідка невідомого походження}

Гріш Фрідріх фон Заксен (1498 - 1510), монета виставлялася для оцінки іiі вартості на сайті «Віоліті» 15 листопада 2010 р. разом із 3 крейцерами герцогства Пфальц-Цвайбрюкен 1598 р. емітент Йоган I. Зображення даного гроша на сторінці вказаного сайту видалене, будь-яка інформація про обставини і місце знахідки нам невідомі.

Як бачимо, більшість знахідок в Україні монет держави Тевтонського ордену в Пруссії зосереджено на теренах історичної Волині та суміжних з нею земель. Саме цей регіон України в середньовічну добу був торговельним партнером міст Тевтонського ордену. Розподіл знахідок монет держави Тевтонського ордену в Пруссії на території сучасної України відповідно до їх емітентів засвідчує, що в українських теренах зустрічаються монети, карбовані у XIV ст., зокрема брактеати та монети емісій Вінріха фон Кніпроде і Конрада фон Юнгінгена. Проте найбільша кількість знахідок монет належить до монет більш пізніх емісій, зокрема Великого магістра Іоганна фон Тіфена. На другому місці за кількісним і якісним показником монети, карбовані в часи Великого магістра Міхаеля Кюхмейстер фон Штернберга, на третьому - монети емісії Великого магістра Мартіна Трухзес фон Ветцхаузена, i на четвертому - монети, карбовані в часи Великого магістра Пауля фон Русдорфа. Тобто, найбільш поширеними на українських теренах є монети Тевтонського ордену, карбовані в 1414 - 1441 pp. та 1477 - 1497 pp.

Здійснений аналіз і систематизація цих знахідок дозволяють зробити деякі висновки: по-перше, монети Великих магістрів Міхаеля Кюхмейстер фон Штернберга та Пауля фон Русдорфа, які разом складають 28,47\% знахідок в Україні монет держави Тевтонського ордену в Пруссії, були поширені не лише на теренах історичної Волині та сусідніх з нею земель, а й на Київщині та Чернігівщині. Проникнення монет указаних магістрів на середньовічні українські землі пов'язане із активною участю Тевтонського ордену у громадянській війні у ВКЛ, в якості союзника великого князя литовського Свидригайла Ольгердовича, що спровокувало чергове військове протистояння з Польщею - польсько-тевтонську війну (1431 1435 рр.). По-друге, знахідки монет Великих магістрів Мартіна Трухзес фон Ветцхаузена та Іоганна фон Тіфена, які разом складають 39,06\% від аналізованих нами монетних знахідок, відображають якісно інший період зв'язків руських земель

${ }^{1}$ Orlyk V. A Coin Hoard ... - P.93-97. 
ВКЛ та держави Тевтонського ордену в Пруссії після фактичного припинення протистояння Ордену та королівства Польського.

У польській нумізматиці існує термін «згуби», яким характеризуються монети, що знаходяться в культурних шарах поселень, свого часу загублені власниками. Насичення монетами культурних шарів поселень дає можливість їх виявлення під час розкопок або інших робіт. У цьому випадку важко не погодитися 3 тезою Володимира Потіна, що такі монети в момент їхньої втрати мали перебувати б «у населення в значних кількостях» ${ }^{1}$. Дослідження знахідок монет держави Тевтонського ордену в Пруссії на території сучасної України дозволяє зробити висновок про зв'язки (переважно економічні) iï середньовічних земель 3 Тевтонським орденом і про присутність орденських монет у грошовому обігу на українських теренах у XIV - XV ст. Порушена нами проблема потребує подальшої наукової розробки. Перш за все, грунтовного вивчення нумізматичних колекцій Національного музею історії України, обласних та районних краєзнавчих музеїв, звітів Інституту археології НАН України, опублікованих документів XIV - XV ст., фондів Центрального державного історичного архіву України в містах Києві та Львові, а також міських архівів Торуня, Гданська, Калінінграда (Кенігсберга) та ін. Таким чином, для подальшого комплексного дослідження зв'язків українських середньовічних земель із державою Тевтонського ордену в Пруссії необхідно використовувати різнопланові джерела, в тому числі й нумізматичні, серед яких топографія знахідок монет, безперечно, посідає вагоме місце.

\section{Джерела}

1. Архів Національного музею України. - Ф. 1. - Оп. 1. - Спр. 32. - Арк. 2 зв.

2. Архів Національного музею історії України. - Ф. 1. - Оп. 1. - Спр. 32. - Арк. 1 зв. Арк. 3 зв.

\section{Література}

3. Безпалько В., Лукашов Д. Скарб початку XVII ст. із с. Тетерівське Київської обл. // Нові дослідження козацької доби на Україні. - Вип. 21. - Част. 1. - К., 2012. - С. 171-175.

4. Беляшевский Н. Монетне клады Киевской Губернии. - Киев: Тип. Т.Г. КорчакНовитского, 1889.

5. Greim M. Wykopaliska monet w gubernii Podolskiej // Wiadomości NumizmatycznoArcheologicznych 1891 \#2 s.207

6. Haljak G. Livonian Coins XIII-XVIII Century. Part I: Feudal States. Livonian Coins From XIII-XVI Century, Tallinn, 2010, 399 p.

7. Haljak G. Liivimaa seestlingud, lübisched ja pennid XIII-XVI sajand, Tallinn, 2007, $108 \mathrm{~s}$.

8. Демидко С., Погорілець О., Стопенчук С. Дослідження залишків пізньосередньовічного укріплення XVI ст. поблизу смт/ Меджибіж Летичівського р-ну Хмельницької обл. Археологічні дослідження в Україні 2004-2005 pр. Київ-Запоріжжя, 2006. С 8-10.

9. Dutkowski Jaroslaw, Suchanek Adam. Corpus Nummorum Civitatis Thorunensis. - Gdansk: Drukarnia PROMA, 2010. -

10. Івакін Г. Ю. Історичний розвиток Києва XIII - середини XVI ст. (історико-топографічні нариси). К., 1996. 272 с.

11. Котляр М. Ф. Грошовий обіг на території України доби феодалізму. К.: Наук. думка, $1971.174 \mathrm{c}$.

12. Опис монет переданих до Мюнц-кабінету університету св. Володимира зі скарбу знайдено в 1897 р. в селі Велика Мощаниця Дубенського повіту.

13. Орлик В. Знахідки на Волині монет банату Северин із символікою Тевтонського ордену. Актуальні проблеми нумізматики у системі спеціальних галузей історичної науки: тези

\footnotetext{
${ }^{1}$ Потин В. М. Введение в нумизматику. Труды Государственного ордена Ленина Эрмитажа. - Ленинград: Искусство, 1986. - T.XXVI. - Ч. 6. - C.114
} 
доп. ІІІ-ї міжнар. наук.-практ. конф, 5-6 листопада 2015 р. Кіровоград-Київ-ПереяславХмельницький, 2015. С. 46-47.

14. Орлик B. Інформаційний потенціал WEB-ресурсів у нумізматичних дослідженнях (на прикладі монет держав хрестоносців). Архівознавство та джерелознавчі галузі знань: проблеми взаємодії на сучасному етапі. Матеріали наук. конф. 3 міжнар. участю 14 березня 2013 р. К., 2013. - С 129-133.

15. Орлик В. Монеты государства Тевтонского ордена в Пруссии в составе денежных и денежно-вещевых кладов, найденных на территории Украины. Наукові записки 3 української історії: Зб. наук. ст. Переяслав-Хмельницький, 2013. Вип. 33. С. 39-45.

16. Орлик В. Обрізаний шилінг магістра Тевтонського ордену Міхаеля Кюхмейстер фон Штернберга знайдений на Львівщині / Василь Михайлович Орлик. // Актуальні проблеми нумізматики у системі спеціальних галузей історичної науки: тези доповідей IV-ï міжнародної науково-практичної конференції, 22-23 червня 2016 р. - КіровоградКиїв-Переяслав-Хмельницький, 2015. - С.54-56.

17. Подаляк Н. Українські землі в системі торговельної мережі німецької Ганзи в XIV ст. Вісник Чернігівського державного педагогічного університету. Серія: історичні науки. Чернігів, 2009. Вип. 73. №6. С.21-25.

18. Позіховський О., Шуст Р. Грошовий обіг на Волині в XIV - XVII століттях (За матеріалами монетних скарбів у фондах Державного історико-культурного заповідника міста Острог Рівненської області) (Додаток. Опис скарбів). Вісник Львівського університету: Серія історична. Львів: Видавництво ЛНУ ім. І. Франка, 2005. Вип. 39-40. C. 543.

19. Потин В. М. Введение в нумизматику. Труды Государственного ордена Ленина Эрмитажа. Ленинград: Искусство, 1986. Т.XXVI. Ч. 6. С. 69-162.

20. Саввов Р. Подольский полугрошек и денежное обращение в Подольском княжестве. Банкаўскі веснік, 2016. №3 (632). С. 16.

21. Сецинский Е. Археологическая карта Подольской губернии, с картой, 3 таблицами планов городищ, указателем географических имен и предметным указателем. Труды одиннадцатого археологического съезда в Киеве в 1899 году. Москва: Тип. Г. Лисснера и А. Гешеля. Т. 1. С. 291.

22. Страшкевич К. Клады, рассмотренные в минц-кабинете университета св. Владимира с 1818 по 1866 гг. Университетские известия. К., 1866. №10. С. 1-38; - №12. - С.9-39

23. Шестопал А. В. Скарби Черкащини. Черкаси: Вид. Андрощук П. С., 2007. 120 с.

24. Miehle D. Monety Zakonu Krzyzackiego/ Katalog monet ziem historycznie z Polska zwiazanych. Zbiory Muzeum Narodowego w Warszawie, Warszawa 1998

25. Orlyk V. A Coin Hoard of Pre-Reform Shillings of the Grand Master Michael Küchmeister von Sternberg Found in Chernihivschyna. Acta Archaeologica Lodziensia, 62, 2016. S. 93-97.

26. Orlyk V. False Coins of the Teutonic Order State in Prussia in the currency of South-Rus Lands of the Lithuanian Grand Duchy. Pieniadz i systemy monetarne wspolne dziedzictwo Europy. Studia i materialy. Augustow - Warszawa, 2012. S. 112-115.

27. Orlyk V. Rare variety of shilling of the Grand Master of the Teutonic Order Paul von Rusdorf found in volyn region, Forum Numizmatyczne: Peniadz i mennice, \#1, Bialystok, 2016, s. 1014.

28. Orłyk W. Rzadki wariant szeląga Zakonu Krzyżackiego z Teofipolskiego skarbu. Biuletyn Numizmatyczny, 4 (388), 2017. S.258-263.

29. Orlyk V. Teutonic Order and the Battle on the Vorksla River in August, 1399 (Numismatic Aspect). Pieniadz a propaganda. Wspolne dziedzictwo Europy, Augustow-Warszawa, 2015. S. 100-104.

30. Orłyk W. Udział wojsk Zakonu Krzyżackiego w bitwie nad rzeką Worsklą w sierpniu 1399 r. w świetle źródeł numizmatycznych / Buletyn Numizmatyczny, Nr 3, 2015, s.175-180.

31. Paszkiewicz B. Brakteaty - pieniądz średniowiecznych Prus. Wrocław, 2009. 488 s. + XIII tablic.

32. Theiner A. Vetera monumenta Poloniae et Lithuaniae gentiumque finitimarum historiam illustrantia maximam partem nondum edita ex tabulariis Vaticanis. Romae: Typis Vaticanis, 1860. T. 1.788 p. 
33. Федоров Д. Монеты Прибалтики XIII-XVIII столетий. Определитель монет. - Таллин, 1966. -423 c.

\section{References}

1. DEMYDKO, S., POHORILETS', O., STOPENCHUK, S. (2006) Doslidzhennya zalyshkiv pizn'oseredn'ovichnoho ukriplennya XVI st. poblyzu smt. Medzhybizh Letychivs'koho r-nu Khmel'nyts'koyi obl. [The study of the remains of the late medieval fortification of the XVI cent. In Medzhybizh Letychivs'k dictrict, Khmel'nyts'kiy region] Arkheolohichni doslidzhennya $v$ Ukrayini 2004-2005 rr. Kyiv-Zaporizhzhya, 8-10. [in Ukrainian].

2. GAJDUKOV, V. P. (2017) 700-letie rossijskogo rublja i kratkij obzor razvitija srednevekovoj russkoj numizmatiki [The 700th anniversary of the Russian ruble and the short review of the Russian Medieval numismatics]. Abstract of papers: Rossijskij rubl'. 700 let istorii. (pp. 5-15). [in Russian].

3. IVAKIN, H. Yu. (1996) Istorychnyj rozvytok Kyyeva XIII - seredyny XVI st. (istorykotopohrafichni narysy). [The historical development of Kiyv in XIII - the middle of XVI cent. (historical-topographical review)] K. 272 [in Ukrainian].

4. KOTLYAR, M. F. (1971) Hroshovyy obih na terytoriyi Ukrayiny doby feodalizmu [The monetary circulation on the territoty of Ukraine in the Feudal period]. K.: Nauk. dumka, 174. [in Ukrainian].

5. Opys monet peredanykh do Myunts-kabinetu universytetu sv. Volodymyra zi skarbu znaydeno v 1897 r. v seli Velyka Moshchanytsya Dubens'koho povitu. [The description of the coins transmitted to tne Numismatic cabinet of the St. Volodymyr University fron the hoard axcavated in 1897 near the village Velyka Moshchanytsya in Dubno county] [in Ukrainian].

6. ORLYK, V. (2015) Znakhidky na Volyni monet banatu Severyn iz symvolikoyu Tevtons'koho ordenu. [The finds of the Teutonic Order coins of the Severyn banat in Volyn] In: Aktual'ni problemy numizmatyky u systemi spetsial'nykh haluzey istorychnoyi nauky: tezy dop. III-yi mizhnar. nauk.-prakt. konf, 5-6 lystopada 2015 r. Kirovohrad-Kyiv-PereyaslavKhmel'nyts'kyy, 46-47. [in Ukrainian].

7. ORLYK, V. (2013) Informatsiynyy potentsial WEB-resursiv u numizmatychnykh doslidzhennyakh (na prykladi monet derzhav khrestonostsiv). [Informatical potential of the WEB-resources in the numismatic researches (by the example of the Crusader coins)] In: Arkhivoznavstvo ta dzhereloznavchi haluzi znan': problemy vzayemodiyi na suchasnomu etapi. Materialy nauk. konf. z mizhnar. uchastyu 14 bereznya 2013 r. K. 129-133. [in Ukrainian].

8. ORLYK, V. (2013) Monety hosudarstva Tevtonskoho ordena $v$ Prussyy $v$ sostave denezhnykh $y$ denezhno-veshchevykh kladov, naydennykh na terrytoryy Ukrayny [The coins of the Teutonic Order in Prussia in the consist of the monetary and material hoards excavated in Ukraine]. Naukovi zapysky z ukrayins'koyi istoriyi: Zb. nauk. st. Pereyaslav-Khmel'nyts'kyy, 33. 39-45. [in Russian].

9. POZIKHOVS'KYY, O., Shust R. (2005) Hroshovyy obih na Volyni v XIV - XVII stolittyakh (Za materialamy monetnykh skarbiv u fondakh Derzhavnoho istoryko-kul'turnoho zapovidnyka mista Ostroh Rivnens'koyi oblasti) (Dodatok. Opys skarbiv). [The monetary circulation in Volyn in XIV - XVII centuries (On the materials of the hoards in the collection of the State historical-cultural reservation in Ostroh (The description of the hoards in addition))] Visnyk L'vivs'koho universytetu: Seriya istorychna. L'viv: Vydavnytstvo LNU im. I. Franka, 39-40. 543. [in Ukrainian].

10. POTYN, V. M. (1986) Vvedenye v numyzmatyku. [The introduction to the numismatics]. Trudy Hosudarstvennoho ordena Lenyna Érmytazha. Lenynhrad: Yskusstvo, Vol.XXVI. (6). 69-162. [in Russian].

11. SAVVOV, R. (2016) Podol'skyy poluhroshek y denezhnoe obrashchenye v Podol'skom knyazhestve [The Podolia half-grosz and the monetary circulation in the Podilya principality]. Bankaŭski vesnik. 3(632). 16. [in Russian].

12. SETSYNSKYY, E. (1901) Arkheolohycheskaya karta Podol'skoy hubernyy, s kartoy, 3 tablytsamy planov horodyshch, ukazatelem heohrafycheskykh ymen y predmetnym ukazatelem. [Archeological map of the Podolia province with the map, 3 charts of the town plans, and the 
geographical mane and general index] In: Trudy odynnadtsatoho arkheolohycheskoho s"ezda $v$ Kyeve v 1899 h. Moskva: Typ. H. Lyssnera i A. Heshelya. 1. 291. [in Russian].

13. STRASHKEVYCH, K. (1866) Klady, rassmotrennye $v$ mynts-kabynete unyversyteta sv. Vladymyra s 1818 po $1866 \mathrm{hh}$. [The hoards incomes to the numismatic cabinet on the St. Volodymyr University from 1818 to 1866] Unyversytetskye yzvestyya. K. 10. 1-38. [in Russian].

14. SHESTOPAL, A. V. (2007) Skarby Cherkashchyny [The hoards of the Cherkassy region]. Cherkasy: Vyd. Androshchuk P. S. 120. [in Ukrainian].

15. ORLYK, V. (2016) A Coin Hoard of Pre-Reform Shillings of the Grand Master Michael Küchmeister von Sternberg Found in Chernihivschyna. Acta Archaeologica Lodziensia, 62. 93-97. [in English].

16. ORLYK, W. Coins of the Teutonic Order contained in the hoard found in the suburbs of the city of Dubno of Rovenska region in march // Pruthenia, X, Olsztyn 2015, s.105-116. [in English].

17. ORLYK, V. (2012) False Coins of the Teutonic Order State in Prussia in the currency of South-Rus Lands of the Lithuanian Grand Duchy. In: Pieniadz i systemy monetarne wspolne dziedzictwo Europy. Studia i materialy. Augustow - Warszawa, 112-115. [in English].

18. ORŁYK, W. (2017) Rzadki wariant szelaga Zakonu Krzyżackiego z Teofipolskiego skarbu [The rare variant of the Teutonic Order szelag from the Teofipol hoard]. Biuletyn Numizmatyczny, 4 (388), 258-263. [in Polish].

19. ORLYK, V. (2015) Teutonic Order and the Battle on the Vorksla River in August, 1399 (Numismatic Aspect). In: Pieniadz a propaganda. Wspolne dziedzictwo Europy, AugustowWarszawa, 100-104. [in English].

20. PASZKIEWICZ, B. (2009) Brakteaty - pieniadz średniowiecznych Prus [Bracteats - the money of the middleage Prussia]. Wrocław, 2009. 488. [in Polish].

21. THEINER, A. (1860) Vetera monumenta Poloniae et Lithuaniae gentiumque finitimarum historiam illustrantia maximam partem nondum edita ex tabulariis Vaticanis [Old monuments of the those of neighboring nations, Lithuania, Poland and the history of notes showing the most part not yet issued the Vatican]. Romae: Typis Vaticanis, 1. 788. [in Latin].

22. MIEHLE, D. (1998) Monety Zakonu Krzyzackiego. Katalog monet ziem historycznie z Polska zwiazanych. Zbiory Muzeum Narodowego w Warszawie [The coins of the Teutonic Order. The catalogue of the coins of lands historically connected with Poland. The collection of the National museum in Warsaw], 192, 780. [in Polish].

\section{Ілюстрації}

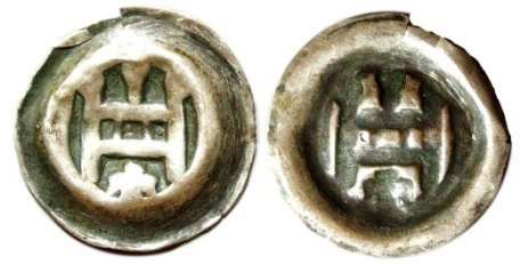

Рис. 1
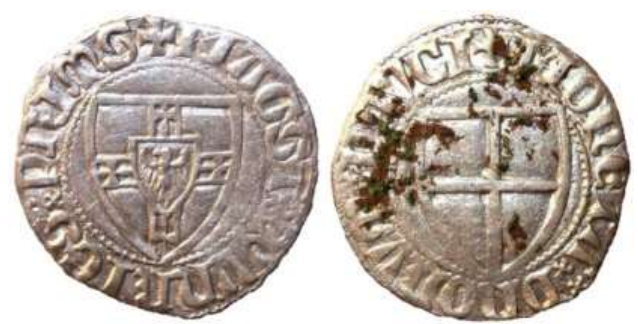

Рис. 3

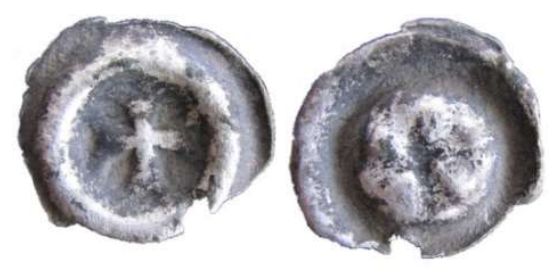

Рис. 2
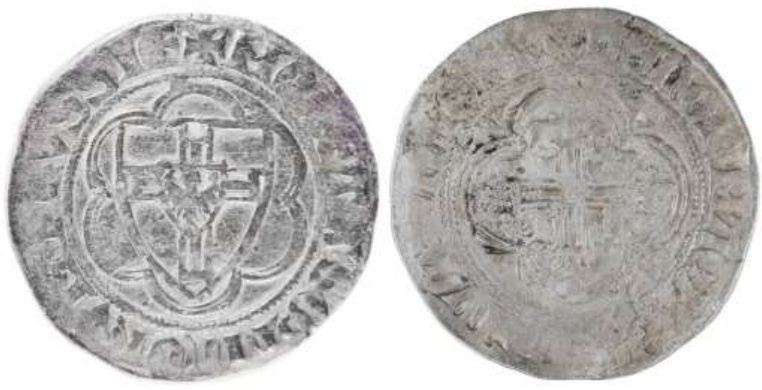

Рис. 4 
The Ukrainian Numismatic Annual, Issue 1.

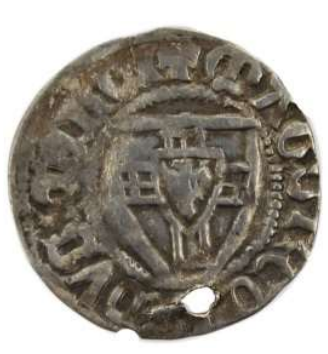

Рис.5

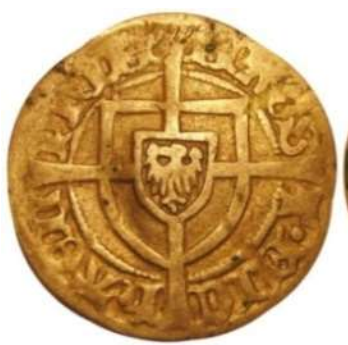

Рис. 7
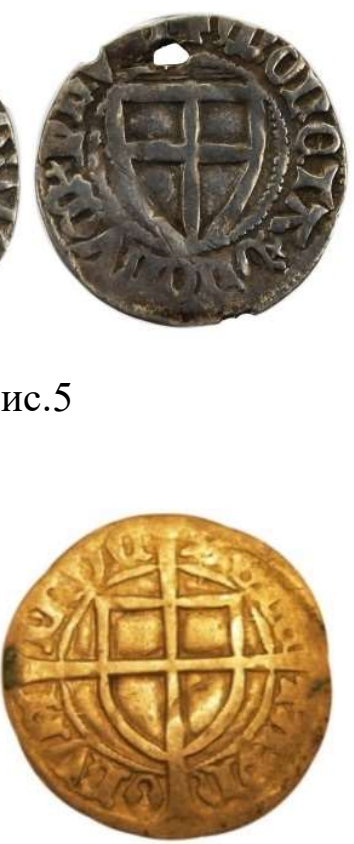

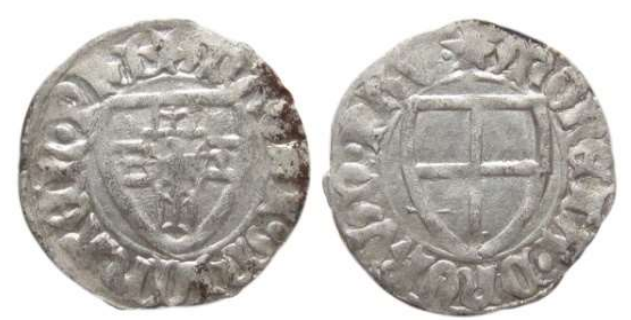

Рис.6

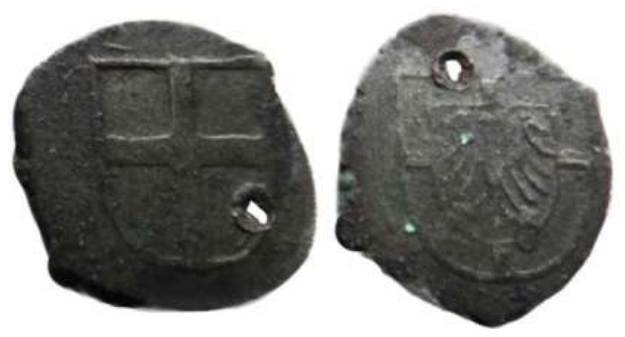

Рис. 8

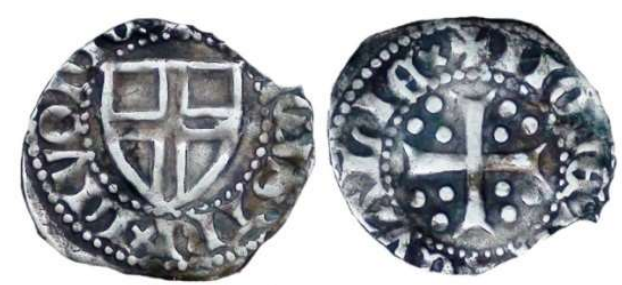

Рис.9 